\title{
Leading properties of GDT auctions for dairy prices
}

\author{
Jakub Olipra \\ Collegium of Management and Finance, Warsaw School of Economics, \\ Warsaw, Poland
}

\begin{abstract}
Purpose - Professionals from the dairy sector commonly believe that the results of Global Dairy Trade (GDT) auctions are a good leading indicator for prices of dairy commodities. The purpose of this paper is to test that hypothesis for prices of key dairy commodities (skimmed milk powder (SMP), whole milk powder (WMP), butter and cheddar) in the main dairy markets (the US, EU and Oceania).

Design/methodology/approach - The leading properties of the GDT auctions are investigated using vector error correction models (VECM).

Findings - The results show that prices at GDT auctions may be treated as a benchmark for global prices of WMP and SMP as they affect prices in all considered markets. However, in case of EU market the relationship with the GDT is bidirectional. GDT prices reveal some leading properties also in cheddar market, however price relationships in this market are much more complex. In case of butter market, GDT can be regarded as a benchmark only for Oceania.

Practical implications - The results of this paper improve knowledge on price transmission in dairy markets, show the role of the GDT auctions in the price setting process, and thus may help professionals from the dairy sector to formulate their price expectations more precisely.

Originality/value - Despite the fact that many professionals from the dairy sector treat GDT auctions as a benchmark, so far their leading properties have not been scientifically proven.
\end{abstract}

Keywords Global Dairy Trade (GDT), Dairy commodities, WMP,SMP, Cheddar, Butter, Prices, Vector error correction

Paper type Research paper

\section{Introduction}

A growing integration of global dairy markets can be observed in the recent years. This largely results from trade liberalization in dairy products which would not be usually possible without deregulation of national dairy markets. Growing integration of global dairy market is reflected i.e. by an increase in correlation between prices of dairy commodities across the world and their higher volatility (European Commission, 2006 and 2017; Keane and O'Connor, 2009; Newton, 2016). Hence, nowadays formulating proper price expectations in the volatile market is crucial for the companies operating in the dairy sector.

Due to the fact that global dairy markets were significantly regulated, the futures markets for dairy commodities are much less developed against the backdrop of other agricultural commodities, especially crops (European Commission, 2017). It is reflected by their relatively low liquidity which negatively affects their price discovery function and limits the opportunity to use them as an effective risk management tool. However, among numerous professionals from the dairy sector there is a common belief that results of dairy commodities auctions at the Internet platform Global Dairy Trade (GDT) owned by Fonterra, have some leading properties for the prices of dairy commodities in the main dairy markets and may be

(C) Jakub Olipra. Published by Emerald Publishing Limited. This article is published under the Creative Commons Attribution (CC BY 4.0) licence. Anyone may reproduce, distribute, translate and create derivative works of this article (for both commercial and non-commercial purposes), subject to full attribution to the original publication and authors. The full terms of this licence may be seen at http:// creativecommons.org/licences/by/4.0/legalcode
Received 18 July 2018 Revised 5 October 2019 30 December 2019 23 February 2020 Accepted 25 February 2020 
$\mathrm{BFJ}$

122,7

2304

treated as a benchmark. The purpose of the research is to test that hypothesis. Although this is a price leadership study, it is largely based on the price transmission mechanism. It results from the fact that the concept of price leadership is grounded in the price transmission mechanism.

The paper is organized as follows. Section 2 provides the literature review in the field of price transmission and price leadership in the global dairy market. Section 3 briefly describes the technical background of the GDT auctions. Section 4 provides information about data collection used in the research. Section 5 describes the econometric methods employed in the research. Section 6 shows the results of the estimations. Section 7 presents concluding remarks.

\section{Literature review}

The price transmission refers to the mechanism how one price affects another price. It can be expressed in terms of the transmission elasticity which measures how a one percent change in one price manifests the change in another price (Minot, 2010). There are two major concepts of price transmission. The first one, horizontal price transmission, refers to the price transmission between prices of the same goods but in different locations, while the second one, vertical price transmission, means the price transmission between prices of the same goods along the different levels of supply chain (Rapsomanikis et al., 2003; Minot, 2010, Kabbiri et al., 2016).

The concept of the price transmission in commodity markets is grounded in the law of one price (LOP). It states that the price difference between the same commodities in two separated markets has to be equal at most the size of the trade costs between these markets (Baffes, 1991; Mundlak and Larson, 1992; Conforti, 2004). LOP can be denoted as:

$$
p_{A}=p_{B}+c
$$

where $p_{A}$ and $p_{B}$ are prices of the same commodity in markets $\mathrm{A}$ and $\mathrm{B}$ while $c$ represents trade costs between these two markets. The difference between prices in these two separated markets cannot exceed the trade costs, or otherwise the profiting opportunities would be exploited by arbitrageurs. While actual prices may diverge from this relation in the short-run e.g. due to delays in transport, the actions of the arbitrageurs will drive down the difference between these two prices toward the level of trade costs in the long term (Rapsomanikis et al., 2003; Listori, 2008).

There is a vast literature on price transmission in agricultural markets, both for vertical (Kinnucan and Forker, 1987; Schroeter and Azzam, 1991; Vavra and Goodwin, 2005; Brosig et al., 2011; Bor et al., 2013) and horizontal one (Rapsomanikis et al., 2003; Ghoshray, 2007; Worako et al., 2008; Goychuk and Meyers, 2014; Newton, 2016). The research on price transmission in agricultural markets is dominated by studies on grains and oilseeds (Zanias, 1993; Thompson et al., 2002; Listori, 2008; Davenport et al., 2016) which are followed by studies on soft commodities like coffee and cocoa (Krivonos, 2004; Worako et al., 2008; Jaramillo-Villanueva and Benitez-Garcia, 2016) and meat (Hahn, 1990; von Cramon-Taubadel, 1998; Bakucs and Ferto, 2006) and dairy (Kinnucan and Forker, 1987; Serra and Godwin, 2003; Capps and Sherwell, 2005; Hahn et al., 2016; Newton, 2016)

An important part of studies on price transmission on agricultural markets is devoted to price benchmarks and price discovery processes which is also an interest of this paper. The majority of studies refer to grains and oilseeds markets (Yang et al., 2003; Ghoshray, 2007; Goychuk and Meyers, 2014; Janzen and Adjeman, 2017; Arnade and Hoffman, 2018; Larre, 2019). They are followed by studies on price leadership in livestock markets (Schroeder and Goodwin, 1990; Carter and MacLaren, 1997; Schroeder, 1997; Lee and Kim, 2007; Piot-Lepetit, 2011) and soft commodities (Bugueiro, 2010). The main conclusions from these studies is that 
that the exporting country with the largest market share effectively sets the world price while other exporters are only adjusting their prices (Ghoshray, 2007). Moreover, multiple benchmarks can exists if the demand for hedging effectiveness outweighs traders' preference for liquidity (Janzen and Adjeman, 2017) while the role of price discovery of particular market may be determined by the seasonal factors (Arnade and Hoffman, 2018).

As far as dairy markets are considered, the majority of literature on price transmission is focused on the price transmission between farm and retail prices. Kinnucan and Forker (1987) found that price transmission between farm and retail prices in the US dairy market is asymmetric. This means that retail prices of dairy products tend to adjust more rapidly to increases in the farm milk price than to decreases. Similar results for the US market were obtained by Lass (2005), Capps and Sherwell (2005), Hahn et al. (2016) and Zeng and Gould (2016). Asymmetry in the price transmission in the dairy markets between farm and retail prices was confirmed also in Brazil (Aguiar and Santana, 2002), Greece (Reziti, 2014), Poland (Fałkowski, 2010) and partly in Spain (Serra and Goodwin, 2003).

There are also some examples of empirical literature on the spatial price transmission in the milk markets. Tluczak (2012) using causality Granger test found that milk prices in Poland depend on prices in France, Germany, Czech Republic and Slovakia, while milk prices in Slovakia are affected by the milk prices in Poland. Relationship among national milk prices in the international milk markets was investigated also by Carvalho et al. (2015). Their results show that the US and New Zealand are the main dairy markets and the shocks on these markets spread out across the world. Vargova and Rajcaniova (2017) analyzed the spatial price transmission between milk markets in Hungary, Poland, Slovakia and Czech Republic. They found that the prices between these four countries are cointegrated, and they confirmed the existence of the LOP in these markets.

The price transmission between the international markets of dairy commodities was profoundly investigated by Newton (2016) using vector autoregressive model (VAR) and vector error correction model (VECM). Results indicate that butter and cheese prices in the US are influenced by prices in both EU and Oceania, while prices in the US affect prices in Oceania. Prices shocks in Oceania spread out to both the EU and the US, while EU prices manifest only in the Oceania. With regards to the prices of milk powders US nonfat dry milk prices are influenced by Oceania and EU skim milk powder prices. Simultaneously, whole milk powder (WMP) prices are influenced by EU WMP prices. The price transmission in the WMP markets was analyzed also by Zhang et al. (2017). Using VECM, they found that the prices of WMP in Oceania, the EU and the US are cointegrated. While Oceania and the EU affect each other, there is no dependence between Oceania and the US despite the unidirectional relationship from the EU to the US. The price transmission in the international skim milk powder markets was investigated by Fousekis and Trachanas (2016) using nonlinear autoregressive distributed lag model. Their results suggest that the skim milk powder prices in the US, the EU and Oceania are linked with stable long-run relationships. Moreover, the pattern of transmission is asymmetric as positive price shocks are transmitted with higher intensity compared to negative price shocks.

The only study on GDT auctions was conducted by Forbes (2010) where WMP prices at GDT auctions were proven to be useful information for forecasting of Free On Board prices of WMP in New Zealand. Nevertheless, the research did not cover other dairy markets. Furthermore, it was conducted shortly after the start of GDT auctions, therefore it does not provide for development of the platform.

\section{Mechanism of the GDT auctions}

GDT is an Internet platform for trading dairy commodity ingredients through an online auction process. GDT is owned by Fonterra, the biggest New Zealand dairy cooperative. 
$\mathrm{BFJ}$

122,7

\section{6}

Figure 1.

Annual quantity sold on the GDT (tonnes)
However, it is operationally and physically separated from Fonterra. The first GDT auction took place on July 2, 2008 and initially auctions were a new sales tool aimed to boost Fonterra's sales. At the beginning, only WMP was traded and auctions were held once a month. Over time, with increasing popularity of GDT auctions, they were joined by new sellers and buyers, new dairy commodities were added to the list of traded products, and since September 3, 2010 auctions have been held twice a month. Currently, GDT has over 500 registered bidders from almost 90 countries and are treated as a benchmark by many professionals (Global Dairy Trade, 2019a). The quantity sold on the GDT had been rapidly growing after the launch of the platform and in 2014 it reached its maximum slightly exceeding 1 million tonnes, see Figure 1. Since then a visible decline in the trade volume had been observed. It can be partially attributed to the adverse weather conditions negatively affecting milk production in New Zealand and Australia where Fonterra, the biggest supplier on the GDT operates. However, in recent years the volume traded on the GDT has stabilized showing the first signs of recovery.

WMP is the main commodity traded on the GDT and in 2018 its share in total sold quantity amounted to $54 \%$. It is followed by skimmed milk powder (SMP) (22\%), anhydrous milk fat $(10 \%)$, butter $(7 \%)$ and cheddar $(4 \%)$. Figure 2 shows the shares of particular

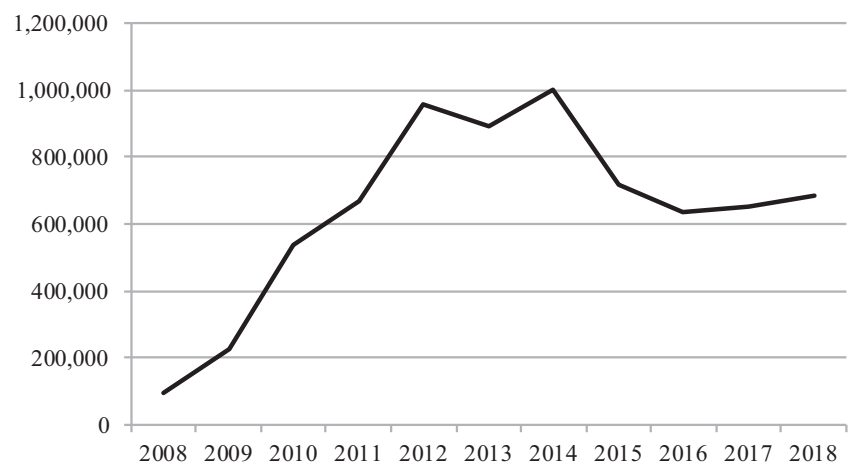

Source(s): GDT website

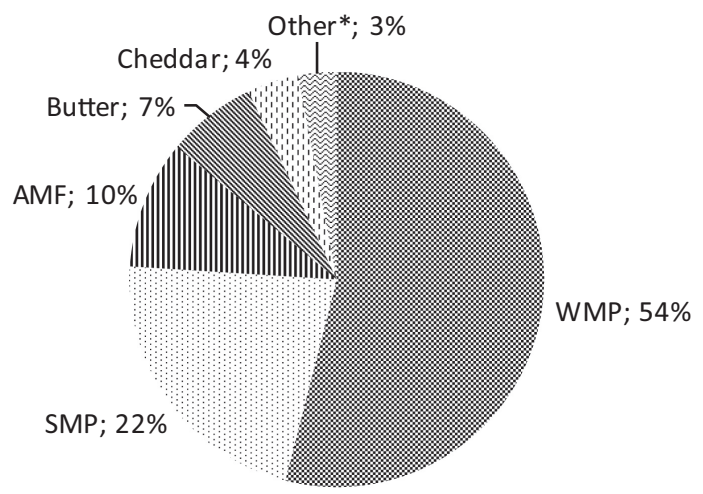

Note(s): * Other includes BMP, Lactose, RenCas and SWP

Source(s): GDT Annual Report 2018
Sold quantity by product group in 2018 
commodities. In 2018, the quantity sold of WMP on the GDT as a share of its global production and exports amounted to $6.9 \%$ and $15.0 \%$, respectively. It is followed by SMP (3.8\% and $6.1 \%$, respectively). The share of other commodities is much lower and in general in 2018 it did not exceed the $1 \%$ in case of production, and 5\% as far as exports are considered. The share of volume of particular commodities traded on the GDT in their global production is presented in Table 1 . The table shows also similar data for the EU, Oceania and the US for the sake of comparison.

The majority of participating bidders come from Asia and Oceania and in 2018 they comprised $55 \%$ of total participating bidders. The share of particular regions in total participating bidders was presented in Figure 3.

GDT auctions are English-type auctions. This means that they start from a pre-announced initial price and price increases round by round until the quantity of bids received for each product matches the quantity on offer for the product. The mechanism of GDT auctions was presented in Figure 4.

Bidders cannot join a GDT auction after its start. This means that they must participate in the first round and in the next rounds they can only maintain or decrease their total bid quantities from the first round. Products can be purchased over six different delivery time periods from one to six months. Two-month contract (CP2), which is also the most active contract traded on the GDT (a 40\% share in total sold quantity in 2018) is used as a settlement for New Zealand's Exchange (NZX) dairy derivatives. It is worth noting that GDT auctions are auctions with the physical delivery. This means that products purchased at the auctions are shipped to the bidder and, contrary to the standard commodity exchanges, there is no opportunity to resign from the delivery before the expiration of contract. GDT auctions last approximately $1.5-2.5 \mathrm{~h}$. Shortly after an auction has concluded, the results are published on the GDT website. All prices are stated in US dollars per MT (US\$/MT) and are specified on a free alongside basis at the specified shipment locations. Average winning price for each commodity is the quantity-weighted average of winning prices at the auction.

There is a visible seasonal pattern of trade volume on the GDT auctions which is associated with the seasonality of milk production in Oceania (New Zealand and Australia). It results from the fact that Oceania is the region where Fonterra, the biggest supplier on the GDT operates. Lagging the trade volume on the GDT by one month vs milk production in Oceania allows to obtain the highest Pearson correlation coefficient between these two variables (0.69). In case of two-month lag it lowers to 0.67 while without any lags the Pearson correlation coefficient for these two variables amounts to 0.50 . It shows the trade volume on the GDT depends on the milk availability in the Oceania in the previous months. The dependence between the trade volume on the GDT auctions and the milk production in Oceania was presented in Figure 5.

\section{Data collection}

Models were estimated on bimonthly price data for WMP, SMP, butter and cheddar from GDT auctions, EU, the US and Oceania. Selected commodities are the most common and frequently traded dairy commodities, while the selection of regions was motivated by their significance in the global trade in dairy products. Oceania, EU and the US represent over $70 \%$ of global exports of dairy products expressed in milk equivalent (FAO, 2019). It may be argued that the EU cheddar prices should not be included in the analysis as cheddar is a niche product in the EU with little consumption beyond the British Isles. Nevertheless, the research on price transmission on agricultural markets states that one of the most important factors determining the degree of price transmission is the product homogeneity (Ghoshray, 2007; Minot, 2010; Kabbiri et al., 2016). Therefore, as cheddar is the only cheese traded on the GDT, its price should be taken also for the EU, even if it is not popular in this 


\begin{tabular}{l} 
BFJ \\
122,7 \\
$\mathbf{2 3 0 8}$ \\
\hline
\end{tabular}

Table 1.

Share of particular regions and the volume trade on the GDT in global production and exports of selected dairy commodities

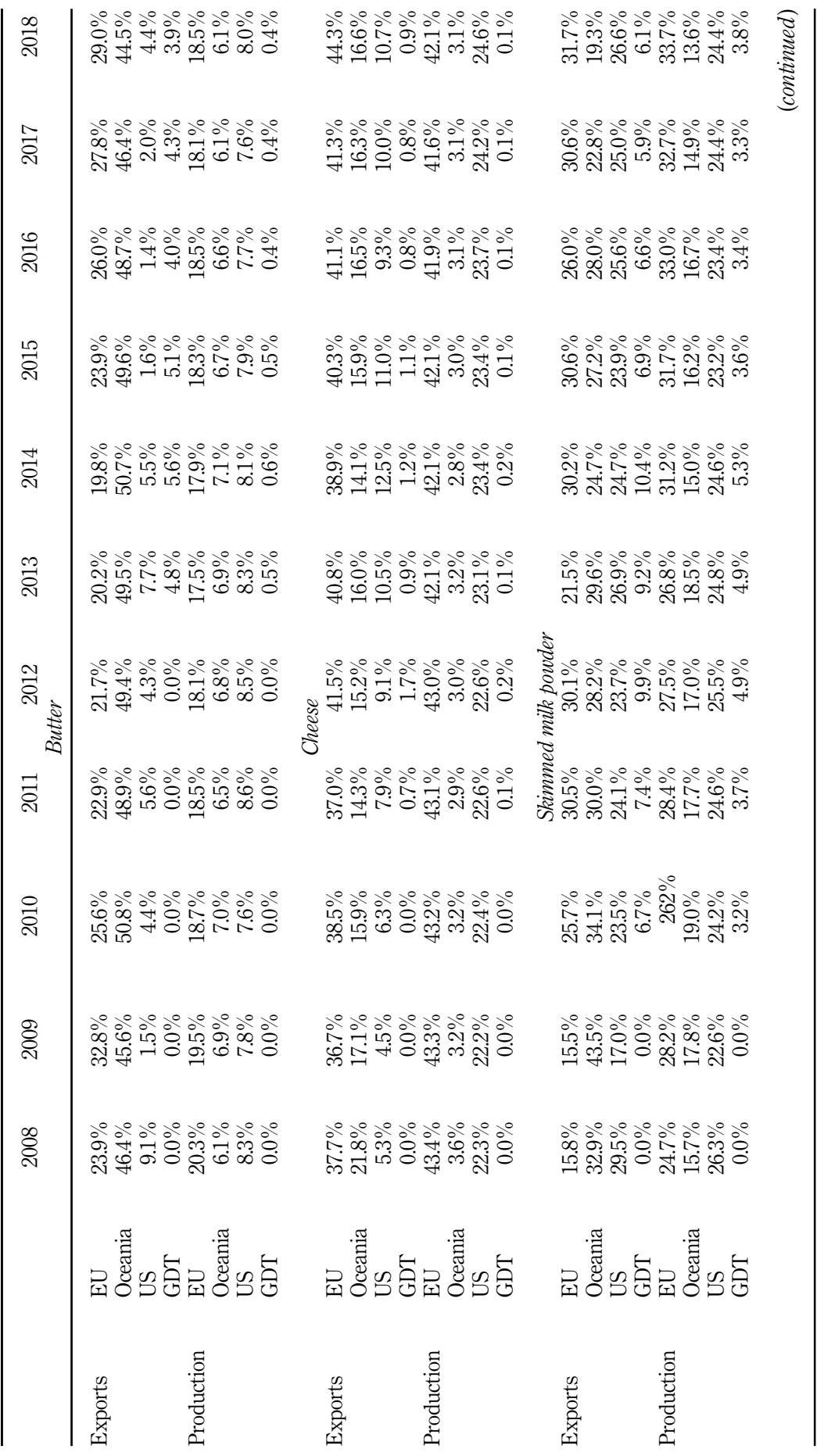




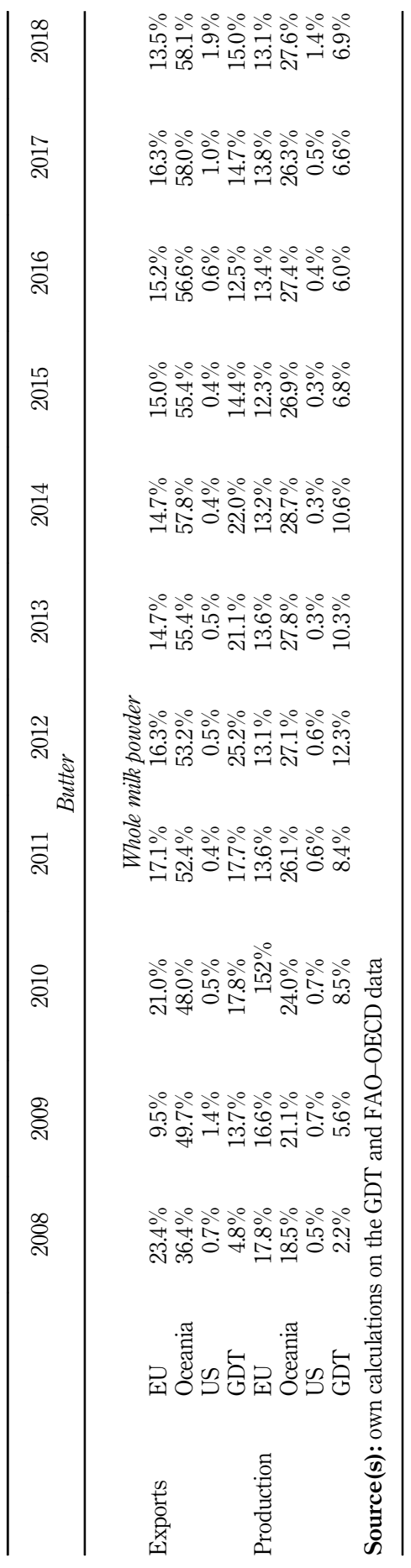

GDT auctions and dairy prices

2309

Table 1 
BFJ

122,7

2310

Figure 3.

Sold quantity by

country group in 2018

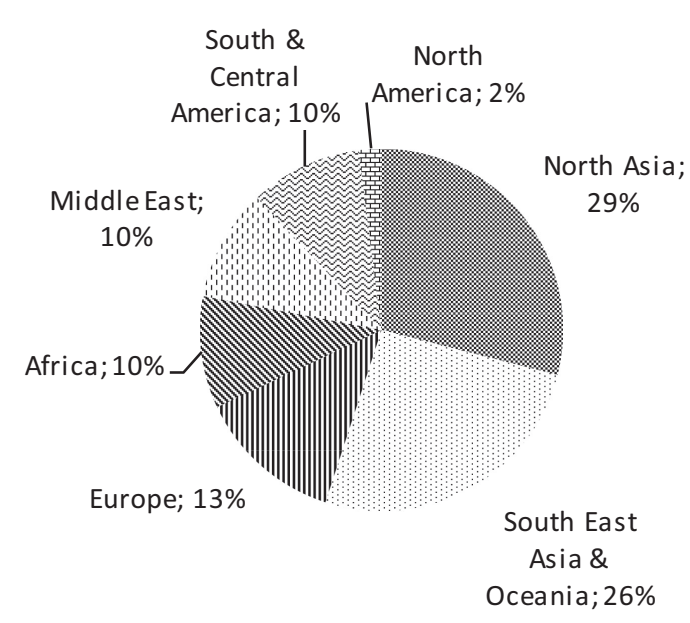

Source(s): GDT Annual Report 2018
Figure 4.

Mechanism of GDT auction

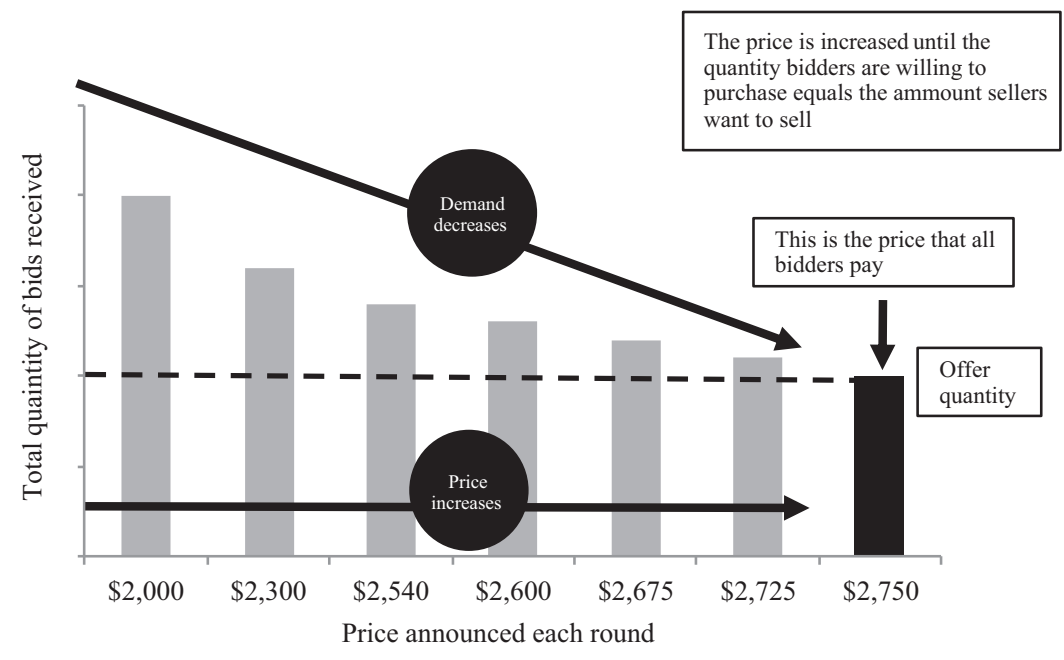

Source(s): Own preparation based on GDT website

region. Inclusion of other sort of cheese for the EU may distort the results of the estimations.

Length of data sample for particular commodities was determined by the availability of the GDT data. GDT auctions have been launched on bimonthly basis in September 2010, initially for WMP and SMP, while some commodities i.e. butter and cheddar were added later. The length of sample in case of particular commodities was presented in Table 2.

Prices of dairy commodities were obtained from a variety of sources. GDT prices were collected from the GDT website. Prices used in the research are the two-month contracts 


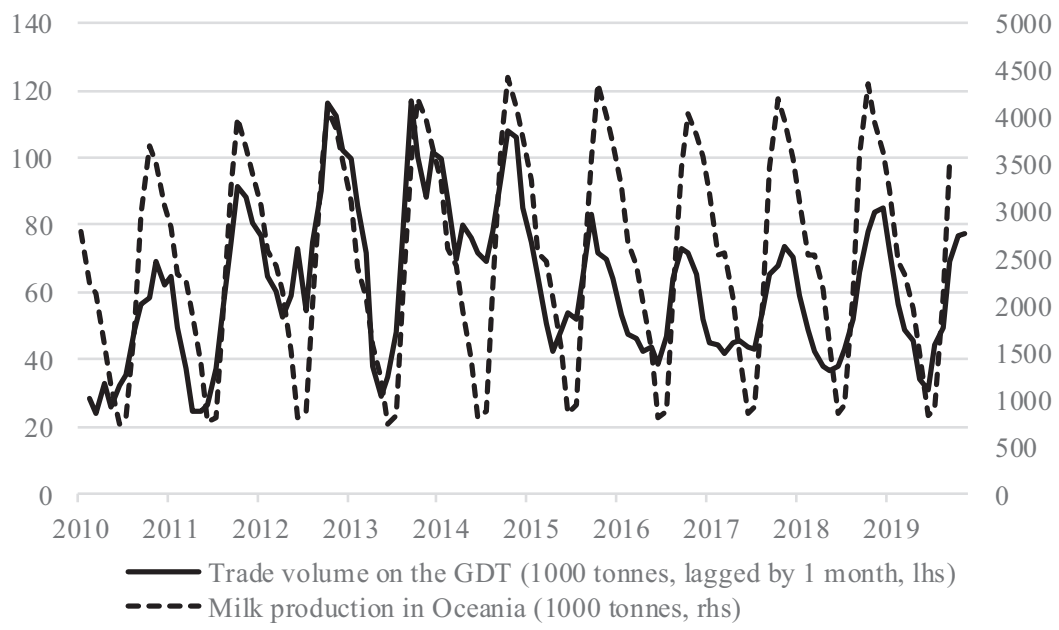

Source(s): Own calculation based on the GDT, DairyAustralia and DCANZ data

\section{GDT auctions and dairy prices}

2311

Figure 5.

Trade volume on the GDT auction vs milk production in Oceania

\begin{tabular}{lc}
\hline Dairy commodity & Sample \\
\hline WMP & $2010-09-01-2019-11-15$ \\
SMP & $2010-09-01-2019-11-15$ \\
Butter & $2013-02-15-2019-11-15$ \\
Cheddar & $2011-07-15-2019-11-15$
\end{tabular}

Source(s): own preparation
Table 2.

Availability of data

(CP2). The main motivation to base the research on the two-month contracts (CP2) is the fact that they are used as settlement for NZX dairy derivatives. Therefore, they can be treated as spot prices. As a consequence their maturity is consistent with prices from other markets included in the research. If the quantity-weighted averages of winning prices for six contract periods (1-6 month delivery periods) were taken there would be a problem of mixture of forward and spot prices which might have bias the results.

Average prices of dairy commodities in the EU were obtained from the EU Milk Market Observatory. Prices are published on weekly basis and are averages of the prices in EU member states weighted by their share in production of the particular commodities.

Average prices of dairy commodities in Oceania were collected from United States Department of Agriculture's (USDA) Dairy Market News (DMN). In case of Oceania DMN reports a price range, listing the lowest price reported to the highest price reported, therefore, in the research their average was taken. Prices come from New Zealand and Australia. There is a possibility that sometimes DMN reports GDT prices as minimum or maximum of Oceania prices. Nevertheless, as the aim of the research is to verify if GDT prices may be treated as a benchmark and a leading indicator it does not cause a problem.

US prices for butter, cheddar and SMP are weekly averages of Chicago Mercantile Exchange spot market prices and weekly averages of WMP prices were collected from USDA's DMN.

Due to the fact that many of the collected time series are reported on the daily or weekly basis they were transformed to bimonthly data using calendar averages. As the second 


\begin{tabular}{|c|c|c|c|c|c|c|}
\hline \multirow{5}{*}{$\begin{array}{l}\text { BFJ } \\
122,7\end{array}$} & & Region & Min & Median & Mean & Max \\
\hline & WMP & US & 2,480 & 3,552 & 3,591 & 4,784 \\
\hline & & $\mathrm{EU}$ & 2,197 & 3,278 & 3,506 & 5,189 \\
\hline & & Oceania & 1,725 & 3,200 & 3,307 & 5,600 \\
\hline & & GDT & 1,814 & 3,162 & 3,259 & 6,283 \\
\hline \multirow{9}{*}{2312} & SMP & US & 1,453 & 2,325 & 2,661 & 4,635 \\
\hline & & $\mathrm{EU}$ & 1,625 & 2,330 & 2,681 & 4,5 \\
\hline & & Oceania & 1,513 & 2,625 & 2,874 & 5,563 \\
\hline & & GDT & 1,350 & 2,554 & 2,802 & 4,901 \\
\hline & Butter & US & 3,069 & 4,753 & 4,652 & 6,661 \\
\hline & & EU & 2,855 & 4,668 & 4,702 & 7,713 \\
\hline & & Oceania & 2,575 & 4,113 & 4,151 & 6,238 \\
\hline & & GDT & 2,300 & 4,015 & 4,067 & 6,560 \\
\hline & Cheddar & US & 2,873 & 3,680 & 3,783 & 5,319 \\
\hline & & $\mathrm{EU}$ & 2,893 & 3,921 & 4,034 & 5,572 \\
\hline tive statistics of & & Oceania & 2,550 & 3,838 & 3,837 & 5,263 \\
\hline dairy commodities & & GDT & 2,514 & 3,554 & 3,633 & 5,261 \\
\hline
\end{tabular}

Source(s): Own calculations on the base of GDT, USDA, EU Milk Market Observatory, Thomson metric tonne Reuters data

auction GDT is always after 14th day of the month the averages were computed in two periods: from the 1st to 14 th and from 15 th to the end of month. All prices are nominated in the US dollar using Thomson Reuters spot rates. If missing values appeared, they were estimated using linear interpolation. All prices were logarithmized. Table 3 reports the descriptive statistics for the time series used in the research before logarithmization. Figure 4 shows the historical price relationships (see Figure 6).

All variables were tested for the presence of unit root. For this purpose, both the augmented Dickey-Fuller (ADF) and the Kwiatkowski-Phillips-Shmidt-Shin (KPSS) tests were evaluated for the log of dairy commodity prices included in the research. As null and alternative hypotheses in ADF and KPSS tests are switched between them, the tests deliver complementary results which minimize the probability of a type II error (Arltova and Fedorowa, 2016). The results lead to the conclusion that in the vast majority of cases logs of the variables included in the research are integrated of order one, Tables 4 and 5. In case of WMP prices on the GDT, butter prices in the US and EU, and cheddar prices in the US tests deliver mixed results. In turn, both tests indicate that cheddar prices on the GDT may be stationary. However, taking into consideration the charts of the aforementioned time series, and their similarity to the other analyzed prices which turned out to be integrated of order one, the results suggesting their stationarity should be treated carefully. As a consequence, it allows to formulate an assumption that they are also integrated of the order one.

\section{Methodology}

The latest research on price transmission and interdependencies in the global dairy market employs VECM (Cervalho et al., 2015; Newton, 2016; Zhang et al., 2017). Such an approach enables to identify long-term and short-term relationships between set of prices. VECM are based on the assumption that nonstationary time series integrated of order one may have at least one cointegrating relationship. In other words, there may exists some value $\beta$ such that $Y_{t}-\beta X_{t}$ is $I(0)$, although $Y_{t}$ and $X_{t}$ are both $I(1)$. In such a case $Y_{t}$ and $X_{t}$ are cointegrated, and they share a common trend (Verbeek, 2004). Such cointegrating relationship may be treated as an approximation of a long-term equilibrium between these variables. The existence of the long-run relationship also has its implications for the short-run behavior of 

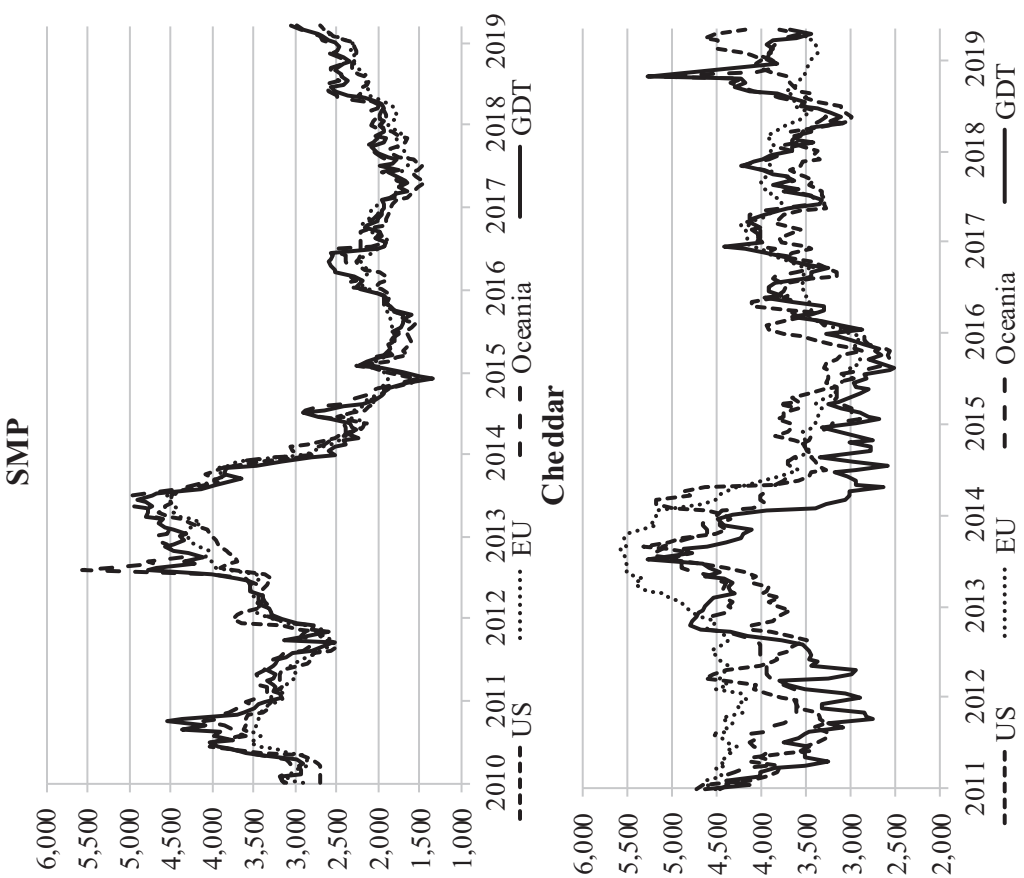

GDT auctions and dairy prices

2313

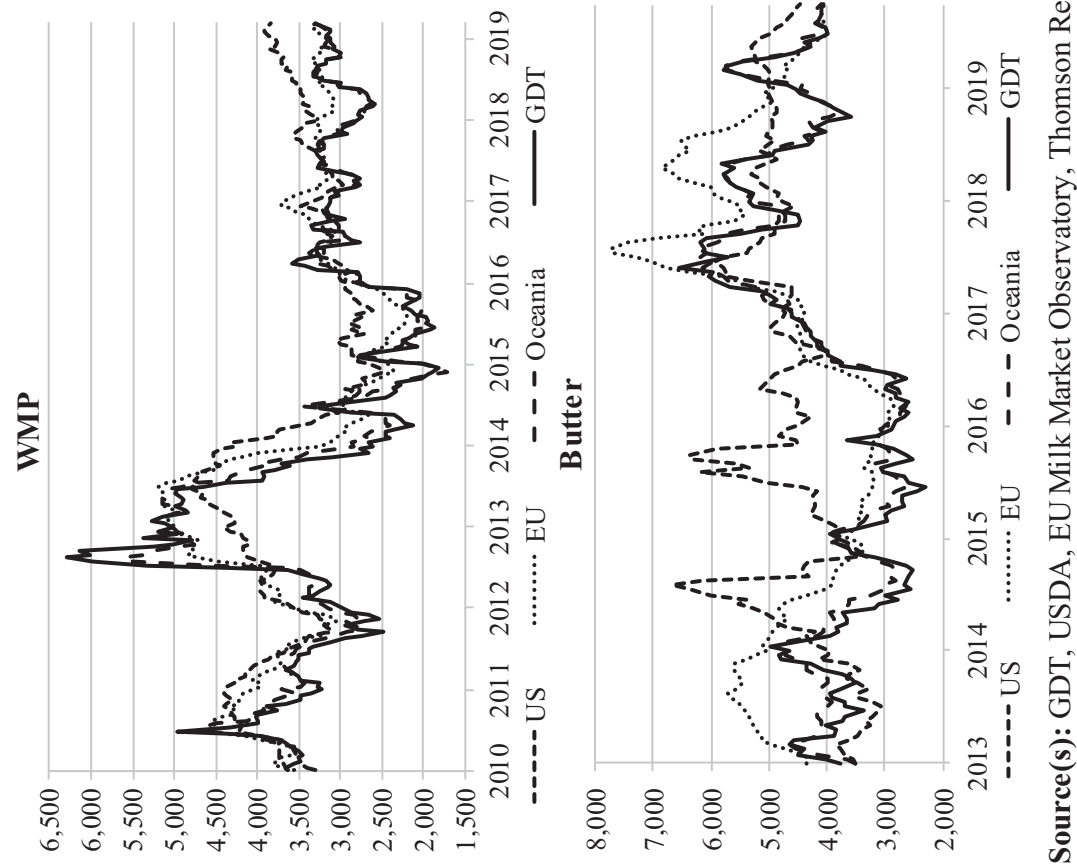

Figure 6.

Prices of dairy commodities, dollars per metric tonne 
BFJ

122,7

\section{4}

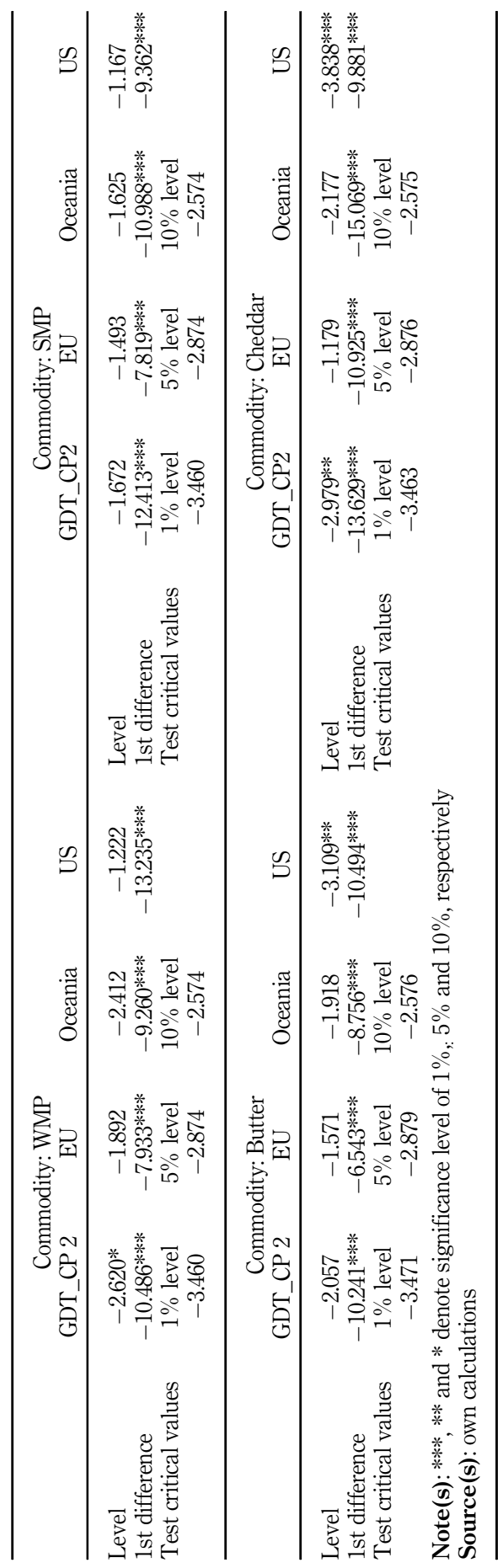

Table 4.

ADF tests for logs of prices 


\begin{tabular}{|c|c|c|c|c|c|c|}
\hline & & GDT_CP2 & $\mathrm{EU}$ & Oceania & US & GDT auctions \\
\hline \multirow[t]{2}{*}{ WMP } & Level & $0.477^{* * *}$ & $0.654^{* *}$ & $0.548 * *$ & $0.616^{* * *}$ & price \\
\hline & 1st difference & 0.055 & 0.089 & 0.063 & 0.112 & \\
\hline \multirow{2}{*}{ SMP } & Level & $1.111 * * *$ & $1.192 * * *$ & $1.099 * * *$ & $1.152^{* * * *}$ & \\
\hline & 1st difference & 0.123 & 0.18 & 0.142 & 0.15 & \\
\hline \multirow[t]{2}{*}{ Butter } & Level & $0.598 * *$ & 0.322 & $0.531 * *$ & $0.741^{* * * *}$ & \\
\hline & 1st difference & 0.063 & 0.122 & 0.068 & 0.064 & 2315 \\
\hline \multirow[t]{2}{*}{ Chedar } & Level & 0.154 & $0.770 * * *$ & $0.359 *$ & $0.359 *$ & \\
\hline & 1st difference & 0.079 & 0.098 & 0.083 & 0.085 & \\
\hline \multirow[t]{2}{*}{ Test critical values } & $1 \%$ level & $5 \%$ level & $10 \%$ level & & & \\
\hline & 0.739 & 0.463 & 0.347 & & & \\
\hline \multicolumn{6}{|c|}{$\begin{array}{l}\text { Note(s): ***, ** and * denote significance level of } 1 \%, 5 \% \text { and } 10 \% \text {, respectively } \\
\text { Source(s): own calculations }\end{array}$} & $\begin{array}{r}\text { KPSS tests for logs of } \\
\text { prices }\end{array}$ \\
\hline
\end{tabular}

the time series, because there has to be some mechanism that enable variables to converge to their long-run equilibrium. This mechanism is defined as error-correction mechanism. It enables to identify the direction of the causality between the cointegrated variables and the speed of the convergence.

The starting point for the VECM model is a $p$-lag $\operatorname{VAR}(p)$ model given by:

$$
Y_{t}=\sum_{i=1}^{p} \Gamma_{i} Y_{t-1}+\varepsilon_{t}
$$

where $Y_{t}$ is a $(n \times 1)$ vector of time series variables, $\Gamma_{i}$ are $(n \times n)$ coefficient matrices, while $\varepsilon_{t}$ is a $(n \times 1)$ vector of error terms. If the variables exhibit a cointegrating relationship, we can transform VAR $(p)$ model into $\operatorname{VECM}(p-1)$ model by subtracting $Y_{t-1}$ from both sides, and then converting the $Y_{t-i}$ terms to $\Delta Y_{t-i+1}$ by successive substitution. A VECM $(\phi-1)$ model is given by:

$$
\Delta Y_{t}=\Pi Y_{t-1}+\sum_{i=1}^{p-1} \Gamma_{i} \Delta Y_{t-1}+\varepsilon_{t}
$$

where $\Delta$ is a first-difference operator, $\Gamma$ represents the transitory effects, while matrix $\Pi$ can be decomposed as the vector or matrix of adjustment parameters $\alpha$ and the vector or matrix of cointegrated vectors $\beta$ :

$$
\Pi=\alpha \beta^{T}
$$

If the variables are cointegrated, then $\operatorname{rank}(\Pi) \neq 0$ and the $\operatorname{rank}(\Pi)$ represents the number of cointegrating vectors.

Hence, during the transformation $\operatorname{VAR}(p)$ into $\operatorname{VECM}(p-1)$, it is imperative to test for the presence of the cointegrating relationship. In this paper, it is done using Johansen (1992) procedure, as it allows to test for more than one cointegrating relationship. The hypothesis of leading properties of GDT auctions is tested on the four sets representing each commodity (WMP, SMP, butter and cheddar), consisting of four prices (GDT, EU, US and Oceania). Therefore, using the Johansen procedure allows to account for the cases where more than one long-run relationship is driving the dynamics of the system of prices. Nevertheless, the drawback of a such approach is that multiple cointegrating vectors lead to the problems with the interpretation of results (Kennedy, 2008).

Johansen's procedure is based on two likehood-ratio tests: the trace test (5) the maximum eigenvalue test (6): 
$\mathrm{BFJ}$

122,7

$$
\begin{gathered}
J_{\text {trace }}(r)=-T \sum_{i=r+1}^{n} \ln \left(1-\widehat{\lambda}_{i}\right) \\
J_{\max }(r)=-T \ln \left(1-\widehat{\lambda}_{i+1}\right)
\end{gathered}
$$

where $T$ is the sample size, $\widehat{\lambda}_{i}$ is the $i$ th ordered eigenvalue from the $\Pi$ matrix, and $r$ represents the number of cointegrating vectors, namely $\operatorname{rank}(\Pi)$. The trace test tests the null hypothesis of $r$ cointegrating vectors against the alternative hypothesis of $n$ cointegrating vectors. In turn, the maximum eigenvalue test tests the null hypothesis of $r$ cointegrating vectors against the alternative hypothesis of $r+1$ cointegrating vectors.

To determine the short-run causal relationship among variables, it is necessary to estimate Granger causality/block exogeneity Wald tests based on the estimated VECM (Toda and Yamamoto, 1995). In the Granger causality approach $x$ is a cause of $y$ if lagged values of $x$ are useful in forecasting of variable $y$. For VECM model for two cointegrated variables a Granger causality test is based on the following equation:

$$
\Delta y_{t}=\alpha e_{t-1}+\gamma_{1} \Delta y_{t-1}+\ldots \gamma_{p} \Delta y_{t-p}+\delta_{1} \Delta x_{t-1}+\ldots \delta_{p} \Delta x_{t-p}+\varepsilon_{t}
$$

where $\gamma$ and $\delta$ are coefficients, $p$ represents the maximum lag of tested variables, while $e_{t-1}$ denotes error correction term. The null hypothesis is that $\delta_{1}=\delta_{2}=\ldots=\delta_{p}=0$ which means that $x$ does not Granger-cause $y$ and it is tested using Wald test.

An important part of inference on the base of VECMs is an analysis of impulse response functions (IRFs). They measure the response of particular variables included in the system to a one-standard-deviation shock on a selected variable along a specified time horizon. Value of IRF function reflecting the response of variable $y_{i}$ to a shock $\rho_{j}$ manifested in period $t$ can be denoted as:

$$
\operatorname{IRF}_{k(i j)}=\frac{\partial y_{i, t+k}}{\partial \rho_{j, t}}
$$

where $k$ denotes number of periods after the shock. Analysis of these functions provides information on how the whole system behaves after the impulse in one variable and how long it takes to stabilize it after the shock.

\section{Results}

In the first step four unconditional VAR models were estimated (for WMP, SMP, cheddar and butter prices). Optimal lag selection was conducted based on the Shwartz (1978) and Hanna and Quinn (1979) criteria. Lag selection was then adjusted based on Lagrange Multiplier (LM) autocorrelation test to receive nonautocorrelated error terms. For reasons of space, the whole procedure and estimates of particular tests and statistics are not discussed in details. The results indicate that two lags are the optimal selection in case of all estimated models.

In the second step, based on the obtained unconditional VAR(p) models, the Johansen (1992) procedure was conducted in order to identify the number of potential cointegrating relationships. Results of the trace tests and maximum eigenvalue tests are presented in Table 6.

The results suggest that in case of SMP model there are three cointegrating equations, in case of cheddar there are two cointegrating equations while in case of butter there is a single cointegrating equation. As far as WMP model is considered tests provide mixed results indicating two or three cointegrating vectors. Finally WMP model was estimated with 3 


\begin{tabular}{|c|c|c|c|c|}
\hline Commodity & Cointegration rank & Trace test & Maximum eigenvalue test & GDT auctions \\
\hline WMP & $\begin{array}{l}r=0 \\
r \leq 1 \\
r \leq 2 \\
r \leq 3\end{array}$ & $\begin{array}{c}106.918^{* * * *} \\
50.444^{* * * *} \\
17.519 \\
3.542\end{array}$ & $\begin{array}{c}56.474^{* * *} \\
32.925^{* * *} \\
13.976^{*} \\
3.542\end{array}$ & prices \\
\hline \multirow[t]{2}{*}{ SMP } & $\begin{array}{l}r=0 \\
r \leq 1\end{array}$ & $\begin{array}{r}103.933^{* * * *} \\
56.019 * * *\end{array}$ & $47.915^{* * * *}$ & 2317 \\
\hline & $\begin{array}{l}r \leq 2 \\
r \leq 3\end{array}$ & $\begin{array}{l}26.376^{* * * *} \\
2.070\end{array}$ & $\begin{array}{l}24.306^{* * * *} \\
2.070\end{array}$ & \\
\hline \multirow[t]{4}{*}{ Butter } & $r=0$ & $82.010^{* * * *}$ & $56.624^{* * * *}$ & \\
\hline & $r \leq 1$ & 25.386 & 15.326 & \\
\hline & $r \leq 2$ & 10.061 & 6.948 & \\
\hline & $r \leq \overline{3}$ & 3.113 & 3.113 & \\
\hline \multirow[t]{4}{*}{ Cheddar } & $r=0$ & $79.295^{* * * *}$ & $41.968^{* * * *}$ & \\
\hline & $r \leq 1$ & $37.326 * *$ & $24.852^{* *}$ & \\
\hline & $r \leq 2$ & 12.474 & 10.340 & \\
\hline & $r \leq 3$ & 2.134 & 2.134 & \\
\hline \multicolumn{5}{|c|}{ Trace test-critical values } \\
\hline & 0.01 & 0.05 & 0.1 & \\
\hline$r=0$ & 61.267 & 54.079 & 50.525 & \\
\hline$r \leq 1$ & 41.195 & 35.193 & 32.268 & \\
\hline$r \leq 2$ & 25.078 & 20.262 & 17.98 & \\
\hline \multirow[t]{2}{*}{$r \leq 3$} & 12.761 & 9.165 & 7.557 & \\
\hline & \multicolumn{3}{|c|}{ Maximum eigenvalue test-critical values } & \\
\hline & 0.01 & 0.05 & 0.1 & \\
\hline$r=0$ & 33.733 & 28.588 & 26.121 & \\
\hline$r \leq 1$ & 27.068 & 22.3 & 20.05 & \\
\hline$r \leq 2$ & 20.161 & 15.892 & 13.906 & le 6 \\
\hline$r<3$ & 12.761 & 9.165 & 7.557 & Johansen cointegration \\
\hline \multicolumn{4}{|c|}{$\begin{array}{l}\text { Note(s): } * * *, * * \text { and } * \text { denote significance level of } 1 \%, 5 \% \text { and } 10 \% \text {, respectively } \\
\text { Source(s): Own calculations }\end{array}$} & $\begin{array}{r}\text { tests for log prices of } \\
\text { dairy commodities }\end{array}$ \\
\hline
\end{tabular}

cointegrating vectors, as the higher number of cointegration vectors potentially increase the stability of the model (Johansen and Juselius, 1990).

In the third step, basing on the results of the Johansen procedure, final VECMs were estimated. In case of VECMs for butter and cheddar restrictions were put on the cointegrating equations in order to test dependence between GDT and the rest of markets.

Table 7 shows that there is a long-term positive relationship between WMP prices on the GDT auctions and the prices in Oceania, EU and the US Prices in Oceania and the US follow GDT prices while in case of EU prices the relationship is bidirectional. This means that any deviations of GDT and EU prices from their long-term equilibrium result in both prices converging to each other in order to regain it. Moreover, deviations from the long-term relationship between GDT and EU prices manifest also in Oceania and US prices. In other words, on the one hand prices in the US and Oceania follow the WMP prices on the GDT auctions, while on the other hand they follow any deviations of EU prices from its long-term relationship with the GDT prices. As far as short-term effects are considered, there is a positive and direct impact of GDT prices on the EU and Oceania prices, while GDT prices are affected by own lag and EU prices. This is confirmed by the Granger causality tests 
BFJ
122,7

\begin{tabular}{|c|c|c|c|c|}
\hline Cointegrating Eq & \multicolumn{2}{|c|}{ CointEq1 } & CointEq2 & CointEq3 \\
\hline EU_WMP(-1) & \multicolumn{2}{|l|}{1} & 0 & 0 \\
\hline OCEAANIA_WMP(-1) & \multicolumn{2}{|c|}{0} & 1 & 0 \\
\hline US_WMP(-1) & & 0 & 1 \\
\hline CDT_WMP_CP2(-1) & \multicolumn{2}{|c|}{-0.955} & -1.028 & -0.787 \\
\hline & \multicolumn{2}{|c|}{-0.449} & 0.209 & -1.837 \\
\hline Error correction & $\Delta \mathrm{EU} \_\mathrm{WMP}$ & $\Delta$ OCEANIA_WMP & $\Delta$ US_WMP & $\Delta \mathrm{GDT}$ _WMP_CP2 \\
\hline CointEq1 & $-0.071 * *(-0.032)$ & $0.150 * * *(-0.054)$ & $0.097 * * *(-0.037)$ & $0.164 * *(-0.083)$ \\
\hline CointEq2 & $0.022(-0.048)$ & $-0.417 * * *(-0.082)$ & $-0.070(-0.056)$ & $0.078(-0.128)$ \\
\hline CointEqS & $0.014(-0.021)$ & $0.055(-0.036)$ & $-0.073^{* * * *(-0.025)}$ & $-0.021(-0.056)$ \\
\hline$\Delta$ EU_WMP(-1) & $0.347^{* * * *}(-0.069)$ & $0.267 * *(-0.118)$ & $0.194 * *(-0.080)$ & $0.328 *(-0.183)$ \\
\hline$\triangle$ OCEANIA_WMP(-1) & $0.051(-0.049)$ & $0.175^{* *}(-0.084)$ & $0.114 * *(-0.057)$ & $0.135(-0.130)$ \\
\hline$\Delta \mathrm{US} \_W M P(-1)$ & $0.014(-0.058)$ & $-0.167 *(-0.099)$ & $-0.027(-0.068)$ & $-0.187(-0.154)$ \\
\hline$\Delta$ GDT_WMP_CP2(-1) & $0.097^{* *}(-0.039)$ & $0.260 * * *(-0.066)$ & $-0.029(-0.045)$ & $0.359 * * *(-0.102)$ \\
\hline \multirow[t]{2}{*}{$R$-squared } & 0.423 & 0.450 & 0.182 & 0.179 \\
\hline & \multicolumn{3}{|c|}{ Statistic } & $p$-value \\
\hline $\mathrm{LM}(1)$ & \multicolumn{3}{|c|}{15.067} & 0.520 \\
\hline LM(I2) & \multicolumn{3}{|c|}{22437} & 0.130 \\
\hline LM(24) & \multicolumn{3}{|c|}{16.654} & 0.408 \\
\hline $\mathrm{J}-\mathrm{B}$ & \multicolumn{3}{|c|}{84.469} & $0.000 * * *$ \\
\hline
\end{tabular}

Table 7. Note(s): Lags and standard errors are in parentheses. ***, ** and * denote significance level of $1 \%, 5 \%$ and VECM model for logs $10 \%$, respectively. Statistically significant price relationships shaded of WMP prices

Source(s): Own calculations

Table 8.

VEC Granger

causality/block

exogeneity Wald tests

- WMP prices

\begin{tabular}{|c|c|c|c|c|c|}
\hline \multicolumn{3}{|c|}{ Dependent variable: $\Delta \mathrm{EU} \_\mathrm{WMP}$} & \multicolumn{3}{|c|}{ Dependent variable: $\Delta$ OCEANIA_WMP } \\
\hline Excluded & Chi-sq & Prob & Excluded & Chi-sq & Prob \\
\hline$\triangle$ OCEANIA_WMP & 1.073 & 0.300 & $\Delta \mathrm{EU} \_W M P$ & 5.169 & $0.023^{* *}$ \\
\hline$\Delta \mathrm{US} \_W M P$ & 0.058 & 0.810 & $\Delta \mathrm{US} \_W M P$ & 2.829 & $0.093^{*}$ \\
\hline$\Delta \mathrm{GDT}$ _WMP_CP2 & 6.31 & $0.012^{* *}$ & $\Delta$ GDT_WMP_CP2 & 15.643 & $0.000 * * *$ \\
\hline All & 16.547 & $0.001^{* * * *}$ & All & 23.213 & $0.000 * * *$ \\
\hline
\end{tabular}

\begin{tabular}{|c|c|c|c|c|c|}
\hline \multicolumn{3}{|c|}{ Dependent variable: $\Delta$ US_WMP } & \multicolumn{3}{|c|}{ Dependent variable: $\Delta \mathrm{GDT}$ WMP $\mathrm{CP} 2$} \\
\hline Excluded & Chi-sq & Prob & Excluded & Chi-sq & Prob \\
\hline$\Delta \mathrm{EU} \_W M P$ & 5.858 & $0.016^{* *}$ & $\Delta \mathrm{EU} \_W M P$ & 3.207 & $0.073^{*}$ \\
\hline$\triangle$ OCEANIA_WMP & 4.022 & $0.045 * *$ & $\triangle$ OCEANIA_WMP & 1.066 & 0.302 \\
\hline$\Delta$ GDT_WMP_CP2 & 0.411 & 0.521 & $\Delta \mathrm{US}$ WMP & 1.461 & 0.227 \\
\hline All & 18.229 & $0.000 * * *$ & All & 6.562 & $0.087 *$ \\
\hline
\end{tabular}

Note(s): ***, ** and * denote significance level of $1 \%, 5 \%$ and $10 \%$, respectively

Source(s): Own calculations

presented in Table 8. The dynamics of the whole adjustment process was shown in Figure 7 which shows the impulse response functions.

Table 9 shows that similarly as in case of WMP prices, there is a long-term positive relationship between SMP prices on the GDT auctions and the prices in Oceania, EU and the 

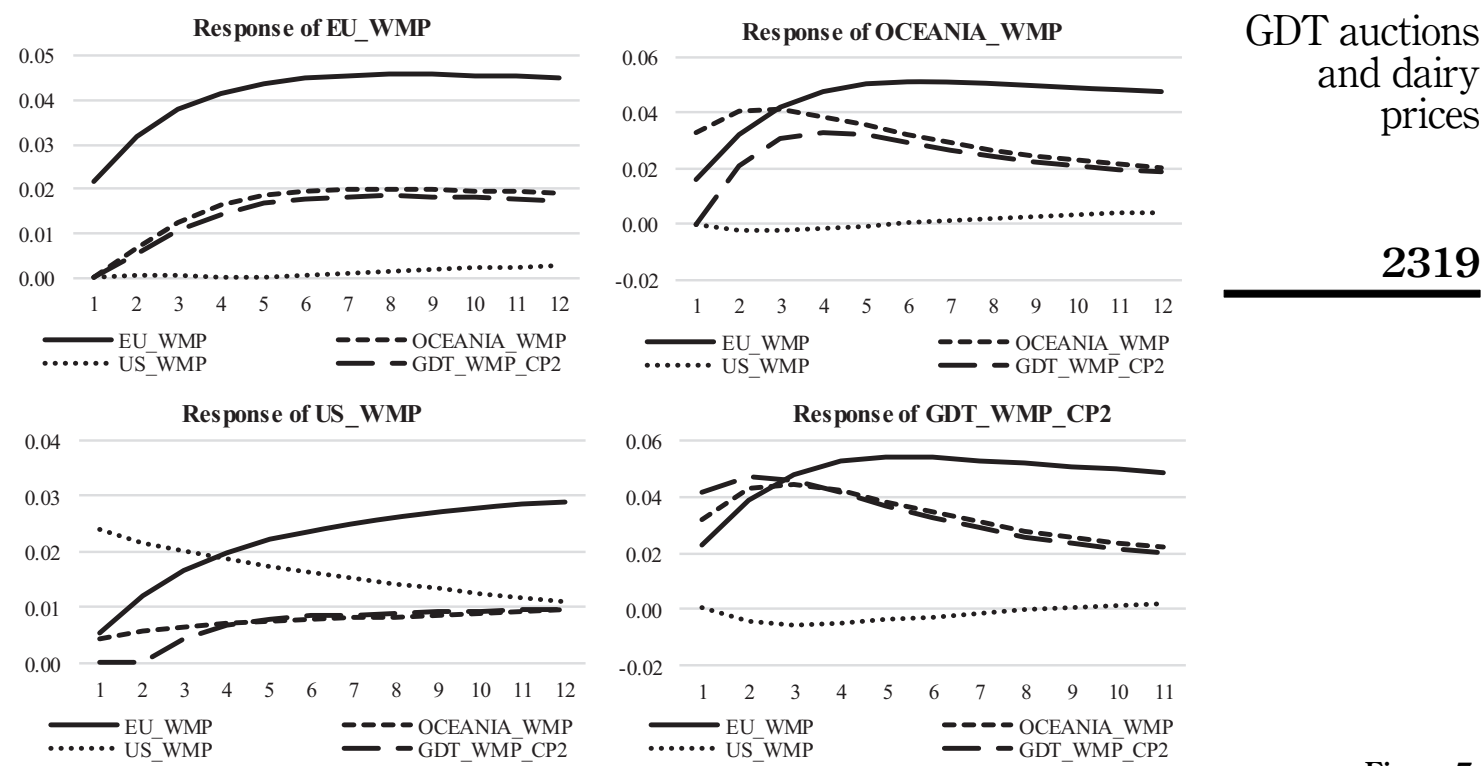

Note(s): X-axis denotes the period following the shock and the y-axis is the magnitude of the impulse response. Impulse is defined as a one standard deviation shock

Source(s): Own calculations

US Prices in Oceania and the US follow SMP prices at the GDT auctions, while relationship between the GDT and EU prices is bidirectional. Similarly as in case of WMP prices, deviations from the long-term relationship between SMP prices on the GDT auctions and in EU manifest also in Oceania and US prices. With regards to the short-term effects GDT prices positively influence the Oceania prices, while GDT prices are impacted by the US and EU prices. This is confirmed by the Granger causality tests presented in Table 10. The dynamics of the whole adjustment process was presented in Figure 8.

Table 11 indicates that there is one long-term relationship between butter prices in the EU, US, Oceania and GDT. While dependence between prices in the US and Oceania, and the GDT is positive, a negative relationship between butter prices in EU and the GDT prices makes the economic interpretation difficult. Such a problem may be connected with the fact that the sample is not long enough to cover full adjustment process in this market. Therefore, the cointegration equation may reflect some temporary equilibrium which is only a proxy for the true long-run relationship between prices in this system. Similar problem was found in Stein and Allen (1997) who analyzed equilibriums in foreign exchange rate markets. As a consequence, at this stage nothing can be done with that as longer time series are needed. Nevertheless, despite its flaws the model provides some information how particular variables react to any deviations from this long-term relationship. Results show that in long-term butter prices in Oceania follow the deviations of GDT prices from the long-term relationship with the system of EU, US and Oceania prices. In turn, GDT prices follow the shocks in system of EU, US and Oceania prices. In short term GDT prices affect EU and US prices. Nevertheless, Granger causality tests suggest that the GDT prices Granger cause only US prices, Table 12. Dynamics of the whole system is presented in Figure 9. 


\section{$\mathrm{BFJ}$ 122,7}

2320

\begin{tabular}{lccc}
\hline Cointegrating Eq & CointEq1 & CointEq2 & CointEq3 \\
\hline EU_SMP(-1) & 1 & 0 & 0 \\
OCEANIA_SMP(-1) & 0 & 1 & 0 \\
US_SMP(-1) & 0 & 0 & 1 \\
GDT_SMP_CP2(-1) & -0.984 & -0.999 & -1.037 \\
C & -0.086 & -0.037 & 0.338 \\
\hline
\end{tabular}

\begin{tabular}{|c|c|c|c|c|}
\hline Error correction & $\Delta$ EU_SMP & $\triangle$ OCEANIA_SMP & $\Delta \mathrm{US} \_\mathrm{SMP}$ & $\Delta \mathrm{GDT}$ SSMP_CP2 \\
\hline CointEq1 & $0.061 * *(-0.026)$ & $0.109 * *(-0.049)$ & $0.112 * *(-0.046)$ & $0.156^{* *}(-0.064)$ \\
\hline CointEq2 & $-0.038(-0.040)$ & $-0,367 * * *(-0.075)$ & $0.068(-0.070)$ & $0.036(-0.098)$ \\
\hline CointEq3 & $0.043 *(-0.023)$ & $0.009(-0.044)$ & $-0.139 * * *(-0.041)$ & $0.041(-0.058)$ \\
\hline$\Delta$ EU_SMP(-1) & $0.364 * * *(-0.064)$ & $0.243 * *(-0.122)$ & $-0.122(-0.114)$ & $0.268^{*}(-0.159)$ \\
\hline$\Delta$ OCEANIA_SMP(-1) & $-0.060(-0.043)$ & $0.013(-0.081)$ & $-0.007(-0.076)$ & $0.061(-0.106)$ \\
\hline$\Delta$ US_SMP(-1) & $0.210 * * *(-0.044)$ & $0.267^{* * * *}(-0.084)$ & $0.601 * * *(-0.078)$ & $0.406 * * *(-0.109)$ \\
\hline$\Delta$ GDT_SMP_CP2(-1) & $0.058(-0.040)$ & $0.154 * *(-0.077)$ & $0.003(-0.072)$ & $0.045(-0.100)$ \\
\hline$R$-squared & 0.476 & 0.376 & 0.271 & 0.211 \\
\hline
\end{tabular}

\begin{tabular}{lrc}
\hline & Statistic & $p$-value \\
\hline LM(1) & 14.371 & 0.571 \\
LM(12) & 12.697 & 0.695 \\
LM(24) & 18.406 & 0.301 \\
J-B & $1,244.742$ & $0.000^{* * *}$
\end{tabular}

Table 9. Note(s): Lags and standard errors are in parentheses. ***, ** and*denote significance level of $1 \% 5 \%$ and VECM model for logs $10 \%$, respectively. Statistically significant price relationships shaded of SMP prices $\quad$ Source(s): Own calculations

Table 10.

VEC Granger causality/block exogeneity Wald tests -SMP prices

\begin{tabular}{|c|c|c|c|c|c|}
\hline \multicolumn{3}{|c|}{ Dependent variable: $\Delta \mathrm{EU}$ SMPP } & \multicolumn{3}{|c|}{ Dependent variable: $\triangle$ OCEANIA_SMP } \\
\hline Excluded & Chi-sq & Prob & Excluded & Chi-sq & Prob \\
\hline$\Delta$ Oceania SMP & 1.965 & 0.161 & $\Delta$ EU_SMP & 3.96 & $0.047^{* *}$ \\
\hline$\Delta$ US_SMP & 22.751 & $0.000 * * *$ & $\Delta$ US_SMP & 10.242 & $0.001^{* * * *}$ \\
\hline$\Delta \mathrm{GDT}$ (SMP_CP2 & 2.068 & 0.150 & $\Delta \mathrm{GDT}$-SMP_CP2 & 4.032 & $0.045^{* *}$ \\
\hline All & 32.101 & $0.000 * * * *$ & All & 30.836 & $0.000^{* * * *}$ \\
\hline
\end{tabular}

\begin{tabular}{|c|c|c|c|c|c|}
\hline \multicolumn{3}{|c|}{ Dependent variable: $\Delta \mathrm{US}$ SMP } & \multicolumn{3}{|c|}{ Dependent variable: $\Delta \mathrm{GDT}$ SMP CP2 } \\
\hline$\underline{\text { Excluded }}$ & Chi-sq & Prob & Excluded & Chi-sq & Prob \\
\hline$\Delta \mathrm{EU}$ SMP & 1.136 & 0.287 & $\Delta \mathrm{EU}$ SMP & 2.838 & $0.092 *$ \\
\hline$\triangle$ OCĒANIA_SMP & 0.008 & 0.930 & $\Delta$ OCĒANIA_SMP & 0.329 & 0.566 \\
\hline$\Delta$ GDT_SMP_CP2 & 0.002 & 0.968 & $\Delta \mathrm{US} \_\mathrm{SMP}$ & 13.9 & 0.000 **** \\
\hline All & 1.472 & 0.689 & All & 28.373 & $0.000 * * *$ \\
\hline
\end{tabular}

Note(s): ***, ** and* denote significance level of $1 \%, 5 \%$, and $10 \%$, respectively

Source(s): Own calculations

Table 13 shows that the system of cheddar prices is driven by two long-term relationships. The cointegrating equations have no economic interpretation as they suggest negative dependence between prices of cheddar on the GDT auctions and in the EU, and negative dependence between prices of cheddar on the GDT auctions and in the US. Similarly, as in case of butter, it may result from the relatively short data sample which most likely does not 

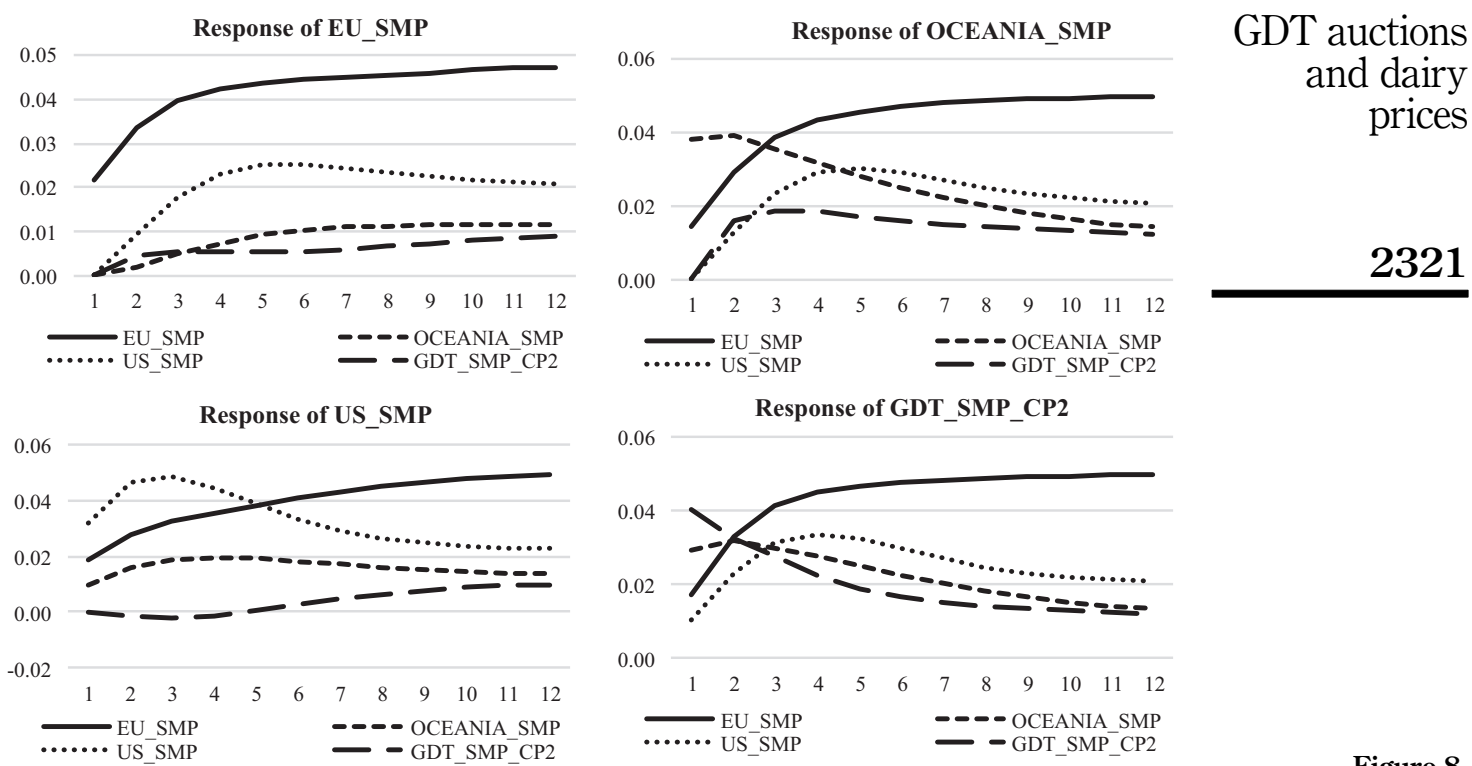

Note(s): X-axis denotes the period following the shock and the y-axis is the magnitude of the impulse response. Impulse is defined as a one standard deviation shock

Source(s): Own calculations

cover the whole adjustment process in this system of prices. It is worth noting, that sample for cheddar is significantly shorter that in case of other analyzed commodities, see Table 2 . The second cointegrating equation implies that there is a positive long-term relationship between prices of cheddar on the GDT auctions and prices of cheddar in the US and Oceania. Results indicate that deviations of GDT cheddar prices from the set of the US and EU prices have leading properties for prices in EU, Oceania and the US Similarly deviations of GDT prices from set of prices in the US and Oceania have a long-term impact on prices in EU and Oceania. It has to be noted that all these long-term relationships are bidirectional as GDT prices in long-run depend on shocks in the systems of US and Oceania, and the EU and US prices. In short-term, there is no statistically significant impact of GDT prices on cheddar prices in other markets. This is confirmed by the Granger causality tests presented in Table 14 . Dynamics of the whole system is shown in Figure 10.

\section{Concluding remarks}

The aim of the research was to test if the GDT auctions are a useful leading indicator for prices of dairy commodities. The hypothesis was tested for prices of key dairy commodities (SMP, WMP, butter and cheddar) in the main dairy markets (the US, EU and Oceania). Results suggest that prices on the GDT auctions may be treated as a benchmark for global WMP prices as in the long-term prices of WMP in EU, Oceania and the US follow the GDT prices. There may be two reasons for such an occurrence. Firstly, WMP is dominant commodity at GDT auctions representing $54 \%$ of total trade in terms of quantity and $15.0 \%$ of its global exports. Therefore, due to the higher liquidity of its market and a significant share in the global trade, the movements of WMP prices on the GDT auctions may more precisely reflect changes in the global market situation. Secondly, Fonterra remains a major seller at the GDT 
BFJ
122,7

Cointegrating Eq

CointEq1

GDT_BUTIER_CP2(-1)

1

EU_BUTTER(-1)

0.130

OCEANIA_BUTTER(-1)

$-1.201$

U S_BUTTER(-1)

$-0.070$

$\mathrm{C}$

1.189

\section{2}

\begin{tabular}{lrrrr}
\hline & $\Delta$ GDT_ & & $\Delta$ OCEANIA_ & \\
Error correction & BUTTER_CP2 & \multicolumn{1}{c}{$\Delta$ BU_BUTTER } & BUTTER & $\Delta$ US_BUTTER \\
\hline CointEq1 & $-0.189^{*}(-0.114)$ & $0.057(-0.046)$ & $0.303^{* * *}(-0.071)$ & $0.115(-0.103)$ \\
$\Delta$ EU_BUTTER(-1) & $0.209^{*}(-0.119)$ & $-0.049(-0.048)$ & $0.119(-0.074)$ & $-0.178^{*}(-0.108)$ \\
$\Delta$ OCEAN1A_BUTTER(-1) & $0.323^{*}(-0.168)$ & $0.515^{* * *(-0.067)}$ & $0.186^{*}(-0.104)$ & $0.027(-0.152)$ \\
$\Delta$ US_BUTTER(-1) & $0.121(-0.144)$ & $0.137^{* *(-0.058)}$ & $0.108(-0.089)$ & $0.089(-0.130)$ \\
$\Delta$ GDT_BUTTER_CP2(-1) & $-0.078(-0.086)$ & $0.076^{* *(-0.035)}$ & $0.040(-0.054)$ & $0.185^{* *(-0.078)}$ \\
$R$-squared & 0.098 & 0.379 & 0.330 & 0.050 \\
\hline & & Statistic & & $p$-value \\
\hline LM(1) & & 17.351 & & 0.363 \\
LM(12) & & 11.085 & 0.745 \\
LM(24) & 36.412 & & $0.003^{* * * *}$ \\
J-B & & 593.229 & $0.000^{* * * *}$
\end{tabular}

Table 11.

VECM for logs of

Note(s): Lags and standard errors are in parentheses. ***, ** and * denote significance level of $1 \%, 5 \%$ and butter prices

$10 \%$, respectively. Statistically significant price relationships shaded

Source(s): own calculations

\begin{tabular}{|c|c|c|c|c|c|}
\hline \multicolumn{3}{|c|}{ Dependent variable: $\Delta$ EU_BUTTER } & \multicolumn{3}{|c|}{ Dependent variable: $\triangle$ OCEANIA_BUTTER } \\
\hline Excluded & Chi-sq & Prob & Excluded & Chi-sq & Prob \\
\hline$\Delta$ GDT_BUTTER_CP2 & 1.052 & 0.305 & $\Delta$ GDT_BUTTER_CP2 & 2.595 & 0.107 \\
\hline$\triangle$ OCEĀNIA_BUTTER & 5.559 & $0.018^{* *}$ & $\triangle$ EU_BUTTER & 3.212 & $0.073^{*}$ \\
\hline$\Delta$ US_BUTTĒR & 4.803 & $0.028 * *$ & $\Delta$ US_BUTTER & 0.57 & 0.450 \\
\hline All & 9.934 & $0.019 * *$ & All & 6.242 & 0.100 \\
\hline \multicolumn{3}{|c|}{ Dependent variable: $\Delta$ US_BUTTER } & \multicolumn{3}{|c|}{ Dependent variable: $\Delta$ GDT_BUTTER_CP2 } \\
\hline Excluded & Chi-sq & Prob & Excluded & $\overline{\text { Chi-sq }}$ & Prob \\
\hline$\Delta$ GDT_BUTTER_CP2 & 2.723 & $0.099 *$ & $\Delta$ EU_BUTTER & 3.715 & $0.054^{*}$ \\
\hline$\triangle$ EU_BUTTER & 0.032 & 0.859 & $\triangle$ OCEANLA_BUTTER & 0.7 & 0.403 \\
\hline$\triangle$ OCEAANIA_BUTTER & 0.463 & 0.496 & $\Delta$ US_BUTTER & 0.815 & 0.367 \\
\hline & 2.889 & 0.409 & All & 6.631 & $0.085^{*}$ \\
\hline \multicolumn{6}{|c|}{$\begin{array}{l}\text { Note(s): ***, ** and } * \text { denote significance level of } 1 \%, 5 \% \text { and } 10 \% \text {, respectively } \\
\text { Source(s): Own calculations }\end{array}$} \\
\hline
\end{tabular}

auctions. Taking into consideration that Fonterra is also the biggest dairy processor in New Zealand with the market share amounting approximately to 84\% (TBD Advisory 2017), while New Zealand is the biggest global exporter of WMP with the $56 \%$ share on global exports (FAO, 2019), Fonterra may have significant influence on the global WMP prices. Therefore, its actions at the GDT auctions may provide significant information about the 

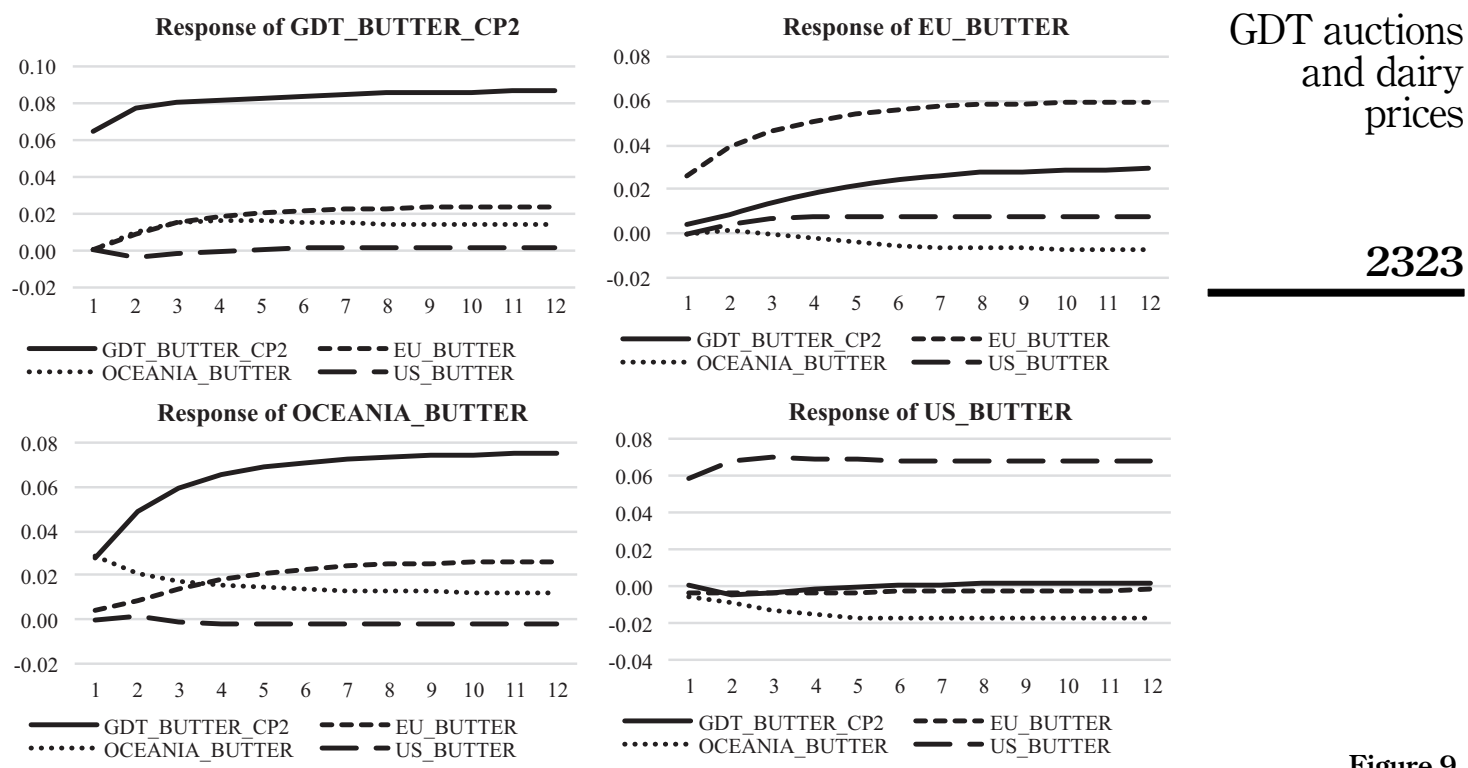

Note(s): X-axis denotes the period following the shock and the y-axis is the magnitude of the impulse response. Impulse is defined as a one standard deviation shock

Source(s): Own calculations

Figure 9.

Impulse response function for logs of butter prices

\begin{tabular}{|c|c|c|c|c|}
\hline Cointegrating Eq & \multicolumn{3}{|c|}{ CointEq1 } & CointEq2 \\
\hline EU CHEDDAR(-1) & \multicolumn{3}{|c|}{0.567} & 0 \\
\hline OCĒANIA_CH EDDAR(-1) & \multicolumn{3}{|c|}{0} & -4.764 \\
\hline US_CHEDD̄AR(-1) & \multirow{2}{*}{\multicolumn{3}{|c|}{$\begin{array}{c}-3.115 \\
1\end{array}$}} & 7.675 \\
\hline GDT_CHEDDAR_CP2(-1) & & & & 1 \\
\hline $\mathrm{C}$ & \multicolumn{3}{|c|}{12.733} & -32.051 \\
\hline Error correction & $\triangle$ EU_CHEDDAR & $\begin{array}{l}\triangle \text { OCEANIA } \\
\text { CHEDDAR }\end{array}$ & $\begin{array}{c}\Delta \mathrm{US}_{-} \\
\text {CHEDDAR }\end{array}$ & $\begin{array}{c}\Delta \mathrm{GDT}_{-} \\
\text {CHEDDAR_CP2 } \\
\end{array}$ \\
\hline CointEq1 & $0.035^{* * *}(-0.012)$ & $0.058 * *(-0.025)$ & $0.062 * *(-0.024)$ & $-0.131^{* * * *}(-0.039)$ \\
\hline CointEq2 & $0.012^{* *}(-0.005)$ & $0.027 * * *(-0.011)$ & $0.008(-0.010)$ & $-0.057 * * *(-0.016)$ \\
\hline$\Delta$ EU_CHEDDAR(-1) & $0.144 *(-0.074)$ & $0.241(-0.150)$ & $-0.109(-0.149)$ & $0.535 * *(-0.235)$ \\
\hline$\triangle$ OCEANIA_CHEDDAR(-1) & $0.059(-0.040)$ & $-0.105(-0.081)$ & $-0.008(-0.081)$ & $0.000(-0.127)$ \\
\hline$\Delta$ US_CHEDDAR(-1) & $0.044(-0.034)$ & $0.082(-0.068)$ & $0.385 * * *(-0.068)$ & $0.228 *(-0.107)$ \\
\hline$\Delta$ GDT_CHEDDAR_CP2(-1) & $-0.012(-0.026)$ & $0.015(-0.052)$ & $0.019(-0.052)$ & $0.087(-0.081)$ \\
\hline \multirow[t]{2}{*}{$R$-squared } & 0.119 & 0.095 & 0.221 & 0.090 \\
\hline & \multicolumn{3}{|c|}{ Statistic } & $p$-value \\
\hline $\operatorname{LM}(1)$ & \multicolumn{3}{|c|}{18.16358} & 0.314 \\
\hline $\mathrm{LM}(12)$ & \multicolumn{3}{|c|}{22.04748} & 0.142 \\
\hline $\mathrm{IM}(2 \mathrm{~A})$ & \multicolumn{3}{|c|}{18.3412} & 0.304 \\
\hline $\mathrm{J}-\mathrm{B}$ & \multicolumn{3}{|c|}{984.4377} & $0.000^{* * * *}$ \\
\hline
\end{tabular}

Note(s): Lags and standard errors are in parentheses. ***, ** and * denote significance level of $1 \%, 5 \%$ and $10 \%$, respectively. Statistically significant price relationships shaded

Source(s): Own calculations

Table 13.

VECM for logs of cheddar prices 
$\mathrm{BFJ}$
122,7

2324

Table 14.

VEC Granger causality/block exogeneity Wald tests - cheddar prices

\begin{tabular}{|c|c|c|c|c|c|}
\hline \multicolumn{3}{|c|}{ Dependent variable: $\Delta \mathrm{EU}$ CHEDDAR } & \multicolumn{3}{|c|}{ Dependent variable: $\triangle$ OCEANIA CHEDDAR } \\
\hline Excluded & Chi-sq & Prob & Excluded & Chi-sq & Prob \\
\hline$\triangle$ OCEANIA CHEDDAR & 2.175 & 0.140 & $\triangle \mathrm{EU} C H E D D A R$ & 2.59 & 0.108 \\
\hline$\Delta \mathrm{US} \_C H E D \bar{D} A R$ & 1.695 & 0.193 & $\triangle \mathrm{US} \_$CHEDDAR & 1.445 & 0.229 \\
\hline$\Delta$ GDT_CHEDDAR_CP2 & 0.232 & 0.630 & $\Delta \mathrm{GDT}$ CHEDDAR CP2 & 0.079 & 0.779 \\
\hline All & 4.355 & 0.226 & All & 4.462 & 0.216 \\
\hline \multicolumn{3}{|c|}{ Dependent variable: $\Delta$ US_CHEDDAR } & \multicolumn{3}{|c|}{ Dependent variable: $\Delta$ GDT_CHEDDAR_CP2 } \\
\hline Excluded & Chi-sq & Prob & Excluded & Chi-sq & Prob \\
\hline$\triangle \mathrm{EU} \_\mathrm{CHEDDAR}$ & 0.536 & 0.464 & $\triangle \mathrm{EU} \_\mathrm{CHEDDAR}$ & 5.169 & $0.023^{* *}$ \\
\hline$\triangle$ OCEANIA_CHEDDAR & 0.01 & 0.922 & $\triangle$ OCEANIA_CHEDDAR & 0 & 1.000 \\
\hline$\Delta$ GDT_CHEDDAR_CP2 & 0.142 & 0.706 & $\triangle \mathrm{US}$ CHEDDAR & 4.571 & $0.033^{* *}$ \\
\hline All & 0.715 & 0.870 & All & 11.663 & $0.009 * * * *$ \\
\hline
\end{tabular}

Note(s): ***, ** and * denote significance level of $1 \%, 5 \%$ and $10 \%$, respectively

Source(s): Own calculations

Figure 10.

Impulse response function for logs of cheddar prices
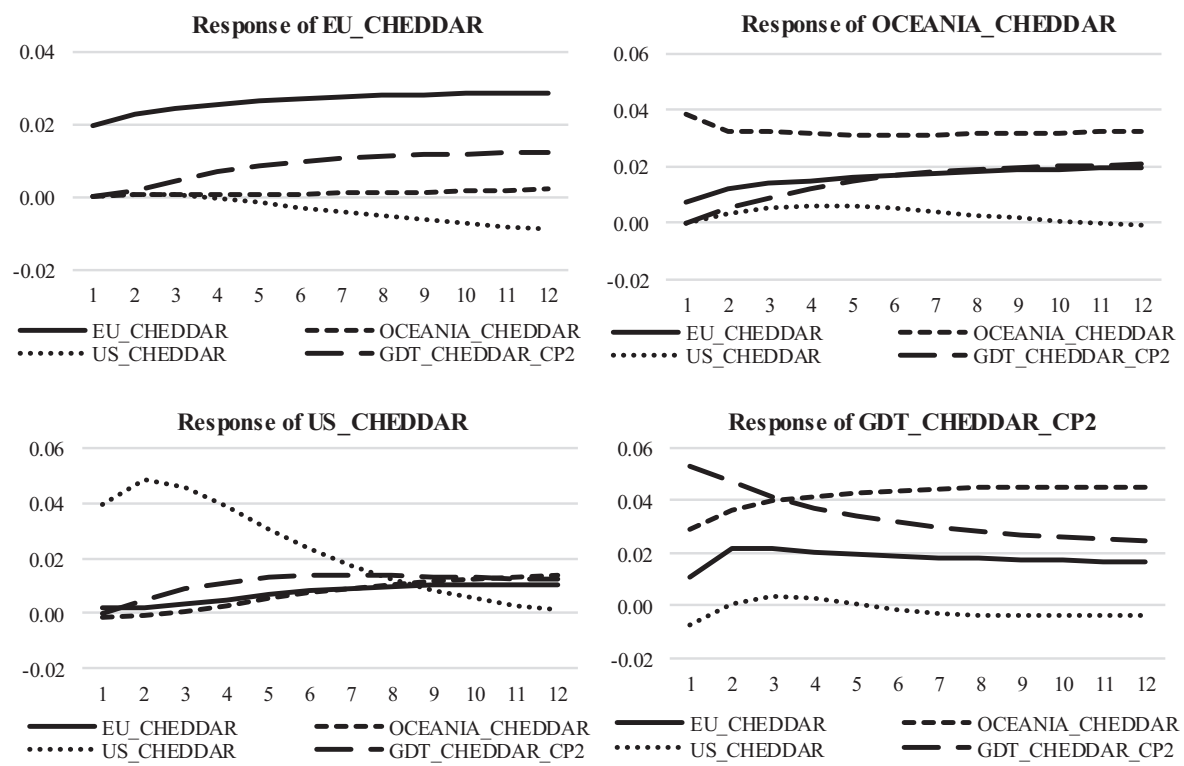

Note(s): X-axis denotes the period following the shock and the y-axis is the magnitude of the impulse response. Impulse is defined as a one standard deviation shock

Source(s): Own calculations

WMP market. Nevertheless, it has to be noted that the long-term relationship between the WMP prices on the GDT auctions and WMP prices in the EU is bidirectional which means that prices on the GDT are also affected by the EU prices. It may results from the fact, that the $\mathrm{EU}$ is the second largest global WMP exporter.

GDT auctions may be treated also as a leading indicator for SMP prices. Similarly as in case of WMP, in the long-term prices of WMP in EU, Oceania and the US follow the GDT 
prices. Leading properties of SMP prices at GDT auctions may result from that SMP is the second commodity at the GDT auctions in terms of quantity. It is noteworthy that the longterm dependence between the GDT and EU prices is bidirectional. It may be caused by the fact that EU is the biggest global exporter of SMP, therefore EU prices may transmit into other markets.

GDT prices reveal some leading properties in cheddar market, however price relationships in this market are much more complex. GDT plays also an important role in the price setting in the global butter market, nevertheless it can be treated as a benchmark only locally in Oceania. It may be a result of relatively low share of these two dairy commodities in quantity sold at the GDT auctions which do not exceed $7 \%$ and $4 \%$, respectively.

The results in general confirm that exporting country with the largest market shares effectively sets the world price while other exporters are adjusting their prices. Moreover, the study confirms that multiple benchmarks can exist if the demand for hedging effectiveness outweighs traders' preference for liquidity. It is the reason for bidirectional dependence like in case of WMP and SMP prices in the EU and on the GDT auctions.

The results of the research contribute to the state of knowledge on the price leadership and price transmission in the dairy markets and thus may help professionals from the dairy sector to formulate their price expectations more precisely. Furthermore, with regards to policy implications, the study underlines the role of benchmarks in price discovery process in agricultural markets. As access to information is one of the most important determinants of price transmission it shows that commodity exchanges like the GDT play a crucial role in the price discovery and the improvement of price transmission in agricultural markets.

\section{References}

Aguiar, D.R.D. and Santana, J.A. (2002), "Asymmetry in farm to retail price transmission: evidence from Brazil”, Agribusiness, Vol. 18, pp. 37-48.

Arltová, M. and Fedorová, D. (2016), "Selection of unit root test on the basis of time series length and value of AR (1) parameter", Statistika - Statistics and Economics Journal, Vol. 96 No. 3, pp. 47-64.

Arnade, C. and Hoffman, L. (2018), "Are corn prices influenced by Brazil's and Ukraine's growing exports?", Proceedings of the Agricultural and Applied Economics Association Annual Meeting, August 5, Washington D.C.

Baffes, J. (1991), "Some further evidence on the law of one price: the law of one price still holds", American Journal of Agricultural Economics, Vol. 73 No. 4, pp. 1264-73.

Bakucs, L.Z. and Ferto, I. (2006), "Marketing margin and price transmission on the Hungarian beef market", Food Economics, Vol. 3 Nos 3-4, pp. 151-160.

Bor, Ö., İsmihan, M. and Bayaner, A. (2013), "Price asymmetry in farm-retail price transmission in the Turkish dairy market”, EY International Congress on Economics, I (EYC2013), October 24-25, Ankara, Turkey.

Brosig, S., Glauben, T, G€otz, L, Weitzel, E.B. and Bayaner, A. (2011), "The Turkish wheat market: spatial price transmission and the impact of transaction costs", Agribusiness, Vol. 27 No. 2, pp. 147-161.

Bugueiro, M., Brümmer, B. and Diaz, J. (2010), "Market integration and price leadership in selected sugar markets. The case of Colombia, Brazil and the world", Economia Agraria, Agrarian Economist Association (AEA), Vol. 14, pp. 1-10.

Capps, O. and Sherwell, P. (2005), "Spatial asymmetry in farm-retail price transmission associated with fluid milk products", Paper Presented at annual meeting of Agricultural and Applied Economics Association, 24 - 27 July, Providence, Rhode Island, available at: http://citeseerx.ist. psu.edu/viewdoc/download?doi510.1.1.577.1880-rep5rep1-type5pdf (accessed 10 August 2017).

Carter, A.C. and MacLaren, D. (1997), "Price or quantity competition? Oligopolistic structures in international commodity markets", Review of International Economics, Vol. 5, No. 3, pp. 373-385. 
BFJ 122,7

Carvalho, G.R., Bessler, D., Hemme, T. and Schroer-Merker, E. (2015), "Understanding Internal Milk Price Relationships", Paper Presented at annual meeting of Southern Agricultural Economics Association, Atlanta, Georgia, 31 January - 3 February, available at: https://ageconsearch. umn.edu/record/196692/files/2015_SAEA_paper_worldmilkprice_Carvalho.pdf (accessed 18 September 2017).

Conforti, P. (2004), "Price transmission in selected agricultural markets", Commodity and Trade Policy Research, Working Paper No 7, Food and Agriculture Organisation, Italy.

von Cramon-Taubadel, S. (1998), "Estimating asymmetric price transmission with the error correction representation: an application to the German pork market", European Review of Agricultural Economics, Vol. 25, pp. 1-18.

Davenport, F., Steigerwald, D. and Sweeney, S. (2016), "Open trade, price supports, and regional price behavior in Mexican maize markets", Economic Geography, Vol. 92, pp. 1-25.

European Commission, (2006), Milk and Milk Products in the European Union, European Commission, Belgium, August.

European Commission, (2017), Managing Risk in the Dairy Sector: How Futures Markets Could Help, EU Agricultural Market Brief no. 11, Belgium, March.

FAO-OECD Agricultural Outlook Database (2019), available at: http://www.agri-outlook.org/data/ (accessed 13 December 2019).

Fałkowski, J. (2010), "Price transmission and market power in a transition context: evidence from the Polish fluid milk sector", Post-communist Economies, Vol. 22 No. 4, pp. 513-529.

Forbes, R. (2010), "Forecasting of New Zealand whole milk powder prices", paper presented at the 2010 New Zealand Agricultural and Resource Economics Society Conference, 26-27 August, Nelson, available at: https://ideas.repec.org/p/ags/nzar10/96945.html (accessed 11 August 2017).

Fousekis, P. and Trachanas, E. (2016), "Price transmission in the international skim milk powder markets", Applied Economics, Vol. 48, pp. 5233-5245.

Ghoshray, A. (2007), "An examination of the relationship between US and Canadian durum wheat prices", Canadian Journal of Agricultural Economics, Vol. 55, pp. 49-62.

Global Dairy Trade (2019a), "GDT Events frequently asked questions”, available at: https:// www.globaldairytrade.info/en/gdt-events/gdt-events-frequently-asked-questions/ (accessed 13 December 2019).

Goychuk, K. and Meyers, W.H. (2014), "Black sea and world wheat market price integration analysis", Canadian Journal of Agricultural Economics, Vol. 62, pp. 245-261.

Hahn, W.F. (1990), "Price transmission asymmetry in pork and beef markets", Journal of Agricultural Economics Research, Vol. 42 No. 4, pp. 21-30.

Hahn, W., Stewart, H., Blayney, D.P. and Davis, C.G. (2016), "Modeling price transmission between farm and retail prices: a soft switches approach", Agricultural Economics, Vol. 47, pp. 193-203.

Hannan, E.J. and Quinn, B.G. (1979), “The Determination of the order of an autoregression”, Journal of the Royal Statistical Society, Vol. 41 Series B, pp. 190-195.

Janzen, J.P. and Adjemian, M.K. (2017), "Estimating the location of world wheat price discovery", American Journal of Agricultural Economics, Vol. 99 No. 5, pp. 1188-1207.

Jaramillo-Villanueva, J.L. and Benítez-García, E. (2016), "Transmisión de precios en el mercado mexicano e internacional de café (Coffea arabica L.): un análisis de cointegración”, Agrociencia, Vol. 50, pp. 931-944.

Johansen, S. and Juselius, K. (1990), "Maximum likelihood estimation and inference on cointegrationwith applications to the demand for money", Oxford Bulletin of Economics and Statistics, Vol. 52 No. 2, pp. 169-210.

Johansen, S. and Juselius, K. (1992), "Testing structural hypotheses in a multivariate cointegration analysis of the PPP and the UIP for UK", Journal of Econometrics, Vol. 53 No. 1, pp. 211-244. 
Kabbiri, R., Dora, M., Elepu, G. and Gellynck, X. (2016), "A global perspective of food market integration: a review", Agrekon, Vol. 55 Nos 1-2, pp. 62-80.

Keane, M. and O'Connor, D. (2009), Price Volatility in the EU Dairy Industry: Causes, Consequences and Coping Mechanisms, Report prepared for European Dairy Association, Belgium, October.

Kennedy, P. (2008), A Guide to Econometrics, 6th ed., Wiley-Blackwell, Hoboken, NJ, Chapter 19.

Kinnucan, H.W. and Forker, O.D. (1987), "Asymmetry in farm-retail price transmission for major dairy products”, American Journal of Agricultural Economics, Vol. 69, pp. 285-292.

Krivonos, E. (2004), "The impact of coffee market reforms on producer prices and price transmission", World Bank Policy Research, Working Paper No. 3358, July, World Bank, Washington, DC.

Larre, G.A. (2019), "Market integration in the international market of soybeans: are GM soy and nonGM soy markets integrated?”, Journal of Agricultural Science, Vol. 11 No. 15, pp. 14-22.

Lass, D.A. (2005), "Asymmetric response of retail milk prices in the northeast revisited”, Agribusiness, Vol. 21, pp. 493-508.

Lee, A.C. and Kim, M. (2007), "Fed cattle price discovery: directed acyclic graph and time series modeling", Paper Presented at Annual Meeting of American Agricultural Economics Association, July 29-August 1 , Portland, Oregon.

Listori, G. (2008), "Price transmission mechanisms: a policy investigation of international wheat markets", Universita' Politecnica delle Marche, Working Papers No. 318, Ancona, Italy.

Minot, N. (2010), "Transmission of world food price changes to markets in Sub-Saharan Africa", Discussion Paper No. 01059, International Food Policy Research Institute, Washington.

Mundlak, Y. and Larson, D. (1992), "On the transmission of world agricultural prices", The World Bank Economic Review, Vol. 6 No. 3, pp. 399-422.

Newton, J. (2016), "Price transmission in global dairy markets", International Food and Agribusiness Management Review, Vol. 19, pp. 57-72.

Piot-Lepetit, I. (2011), "Price volatility and price leadership in the EU beef and pork meat market", in Piot-Lepetit, I. and M'Barek, R. (Eds), Methods to Analyse Agricultural Commodity Price Volatility, Springer New York, NY, pp. 85-105.

Rapsomanikis, G., Hallam, D. and Conforti, P. (2003), "Market integration and price transmission in selected food and cash crop markets of developing countries: review and applications", Commodity Market Review 2003-2004, Food and Agriculture Organization of the United Nations (FAO), pp. 51-76, available at: http://www.fao.org/3/y5117e/y5117e00.htm\#Contents.

Reziti, I. (2014), "Price transmission analysis in the Greek milk market", SPOUDAI Journal of Economics and Business, Vol. 64 No. 4, pp. 75-86.

TDB Advisory (2017), "New Zealand dairy companies review”, available at: https:/www.tdb.co.nz/wpcontent/uploads/2016/05/TDB-Dairy-Companies-Review.pdf (accessed 19 September 2017).

Schroeder, T.C. (1997), "Fed cattle spatial transactions price relationships", Journal of Agricultural and Applied Economics, Vol. 29 No. 2, pp. 347-362.

Schroeter, J.R. and Azzam, A. (1991), "Marketing margins, market power, and price uncertainty", American Journal of Agricultural Economics, Vol. 73, pp. 990-999.

Schroeder, T.C. and Goodwin, B.K. (1990), "Regional fed cattle price dynamics", Western Journal of Agricultural Economics, Vol. 15, pp. 111-122.

Schwarz, G. (1978), "Estimating the dimension of a model", The Annals of Statistics, Vol. 6 No. 2, pp. $461-464$.

Serra, T. and Goodwin, B.K. (2003), "Price transmission and asymmetric adjustment in the Spanish dairy sector", Applied Economics, Vol. 35 No 18, pp. 1889-1899.

Stein, J.L. and Allen, P.R. (1997), Fundamental Determinants of Exchange Rates, Clarendon Press, Oxford. 
$\mathrm{BFJ}$

122,7

2328

Thompson, S., Gohout, W. and Herrmann, R. (2002), "CAP reforms in the 1990s and their price and welfare implications: the case of wheat", Journal of Agricultural Economics, Vol. 53, pp. 1-13.

Toda, H.Y. and Yamamoto, T. (1995), "Statistical inference in vector auto-regressions with possibly integrated processes", Journal of Econometrics, Vol. 66, pp. 225-250.

Tłuczak, A. (2012), "Attempt to identify the causal relationships between the prices of milk in selected EU countries", Acta Oeconomica et Informatica, Vol. 15 No. 2, pp. 1-3.

Vargova, L. and Rajcaniova, M. (2017), "Spatial price transmission of milk prices among the Visegrad countries", Visegrad Joumal on Bioeconomy and Sustainable Development, Vol. 6 No. 2, pp. 79-83.

Vavra, P. and Goodwin, B.K. (2005), "Analysis of price transmission along the food chain", OECD Food, Agriculture and Fisheries Papers No. 3, France, available at: https://www.oecd-ilibrary. org/agriculture-and-food/analysis-of-price-transmission-along-the-food-chain_752335872456.

Verbeek, M. (2004), A Guide to Modern Econometrics, 2nd ed., John Wiley and Sons, Hoboken, NJ, Chapter 10.

Worako, T.K., van Schalkwyk, H.D., Aelemu, Z.G. and Ayele, G. (2008), "Producer price and price transmission in a deregulated Ethiopian coffee market", Agrekon, Vol. 47, pp. 492-508.

Yang, J., Zhang, J. and Leatham, D.J. (2003), "Price and volatility transmission in international wheat futures", Annals of Economics and Finance, Vol. 4 No. 1, pp. 37-50.

Zanias, G. (1993), "Testing for integration in European Community agricultural product markets", Journal of Agricultural Economics, Vol. 44, pp. 418-427.

Zeng, S. and Gould, B. (2016), "Is there asymmetric price transmission in the US Fluid milk market?", Agricultural and Applied Economics Association Annual Meeting, July 31-August 2, Boston.

Zhang, J., Brown, C., Dong, X. and Waldron, S. (2017), "Price transmission in whole milk powder markets: implications for the Oceania dairy sector of changing market developments", New Zealand Journal of Agricultural Research, Vol. 60 No. 2, pp. 140-153.

\section{Further Reading}

DC AGRI (2019), Data on EU Dairy Commodities Prices, EU Milk Market Observatory, available at: https://ec.europa.eu/agriculture/market-observatory/milk.

Food and Agriculture Organization (2019), "Dairy market review”, Rome, available at: http://www.fao. org/3/ca3879en/ca3879en.pdf (accessed 1 December 2019).

Global Dairy Trade (2016), "Summary of price discovery process", available at: https://www. globaldairytrade.info/assets/Uploads/resources/GDT-Summary-of-Price-Discovery-Process-Oct16.pdf (accessed 13 Deceber 2019).

Global Dairy Trade (2019b), "Global dairy trade annual report 2018”, available at: https://www. globaldairytrade.info/en/about-us/announcements/gdt-publishes-2018-annual-report/ (accessed 13 December 2019).

USDA's Dairy Market News, (2019), "Data on US and Oceania dairy commodities prices", available at: https://www.marketnews.usda.gov/mnp/da-report-config.

\section{Corresponding author}

Jakub Olipra can be contacted at: jakub.olipra@gmail.com

For instructions on how to order reprints of this article, please visit our website:

www.emeraldgrouppublishing.com/licensing/reprints.htm

Or contact us for further details: permissions@emeraldinsight.com 